\title{
Nanoceria Seed Priming Improves Salt Tolerance in Rapeseed Through Modulating ROS Homeostasis and a-Amylase Activities
}

\section{Mohammad Nauman Khan}

Huazhong Agricultural University

\section{Yanhui Li}

Huazhong Agricultural University

\section{Zaid Khan}

Huazhong Agricultural University

\section{Linlin Chen}

Huazhong Agricultural University

Jiahao Liu

Huazhong Agricultural University

Jin Hu

Huazhong Agricultural University

Honghong Wu ( $\nabla$ honghong.wu@mail.hzau.edu.cn )

Huazhong Agricultural University https://orcid.org/0000-0001-6629-0280

\section{Zhaohu Li}

Huazhong Agricultural University

\section{Research}

Keywords: Nanoceria, salt stress, seed priming, ROS homeostasis, a-amylase activity, $\mathrm{Na}+\mathrm{K}+$ ratio

Posted Date: June 24th, 2021

DOl: https://doi.org/10.21203/rs.3.rs-642905/v1

License: (c) (1) This work is licensed under a Creative Commons Attribution 4.0 International License. Read Full License 


\section{Abstract}

Background: Salinity is a big threat to agriculture by limiting crop production. Nanopriming (seed priming with nanomaterials) is an emerged approach to improve plant stress tolerance; however, our knowledge about the underlying mechanisms is limited.

Results: We used cerium oxide nanoparticles (nanoceria) to prime rapeseeds and investigated the possible mechanisms behind nanoceria improved rapeseed salt tolerance. We synthesized and characterized polyacrylic acid coated nanoceria (PNC, $8.5 \pm 0.2 \mathrm{~nm},-43.3 \pm 6.3 \mathrm{mV}$ ) and monitored its distribution in different tissues of the seed during the imbibition period ( 1,3 , 8h priming). Our results showed that compared with the no nanoparticle control, PNC nanopriming improved germination rate $(12 \%)$ and biomass $(41 \%)$ in rapeseeds under salt stress $(200 \mathrm{mM} \mathrm{NaCl})$. During the priming hours, PNC were located mostly in the seed coat, nevertheless the intensity of PNC in cotyledon and radicle was increased alongside with the increase of priming hours. During the priming hours, the amount of the absorbed water $(52 \%, 14 \%, 12 \%$ increase at $1,3,8 \mathrm{~h}$ priming, respectively) and the activities of a-amylase were significantly higher $(175 \%, 309 \%, 295 \%$ increase at 1, 3, 8h priming, respectively) in PNC treatment than the control. PNC primed rapeseeds showed significantly lower content of $M D A, \mathrm{H}_{2} \mathrm{O}_{2}$, and ${ }^{\circ} \mathrm{O}_{2}{ }^{-}$in both shoot and root than the control under salt stress. Also, under salt stress, PNC nanopriming enabled significantly higher $\mathrm{K}^{+}$retention $(29 \%)$ and also significantly lower $\mathrm{Na}^{+}$accumulation $(18.5 \%)$ and $\mathrm{Na}^{+} / \mathrm{K}^{+}$ ratio $(37 \%)$ than the control.

Conclusions: Our results suggested that besides the more absorbed water and increased a-amylase activities, PNC nanopriming improves salt tolerance in rapeseeds through maintaining ROS homeostasis and $\mathrm{Na}^{+} / \mathrm{K}^{+}$ratio. It adds more knowledge regarding the mechanisms underlying nanopriming improved plant salt tolerance.

\section{Background}

Rapeseed (Brassica napus L.) is one of the important oilseed crops in the world [1]. In the past decade, the rapeseed total harvested area, productivity, and annual grain yield increased by $17.6 \%$ (29.534.7 million ha), $50.3 \%$ (50.6-76.1 million tons), and $27.8 \%$ (1716-2194 $\mathrm{kg}$ ha) respectively, reflecting that the demand for rapeseed is continuing to increase [2]. However, stresses such as drought, salinity, and heat limit rapeseed production [3]. Generally, about 20\% ( 953 million ha) of the total global land is salt-affected [3]. Salinity is one of the major stresses impairing seed germination ability or resulting longer germination time $[4,5]$. Besides seed germination, salinity stress affects the performance of rapeseed plants in early seedling growth stage, inhibits photosynthetic functions in vegetative growth stage, and reduces seed production [6, 7]. 
In general, seed germination is the first step of establishing a plant. The process of seed germination is categorized into three subsequent phases: (1) imbibition phase (water absorption), (2) lag phase (reserves metabolism), and (3) radical protrusion [8]. To improve seed germination under hostile conditions, many techniques have been applied in agricultural practice. Seed priming is one of the widely adopted techniques. During the process of priming, seeds are imbibed in a solution containing certain solutes for the activation of pre-germinative metabolism while not allowing the seed to fully germinate [1]. Among the priming techniques, seed nanopriming which uses nanomaterials to prime seeds, has been reported to be successfully applied for improving germination and stress tolerance of seedlings [9]. Nanoparticles (NPs) such as AgNPs and $\mathrm{Fe}_{2} \mathrm{O}_{3}$ were documented to improve seed development by enhancing starch metabolism and triggering Fe acquisition in wheat and rice [10]. Seed priming in lupine with $\mathrm{ZnO} \mathrm{NPs}$ played an important role in $\mathrm{NaCl}$ stress tolerance via enhancing antioxidant activities and $\mathrm{Na}^{+}$adjustment [11]. Similarly, in wheat crops, AgNPs modulated hormonal balance while improved seed germination and salinity tolerance [12].

Cerium oxide nanoparticles (nanoceria, $\mathrm{CeO}_{2}$-NPs), due to their unique catalytic ROS (reactive oxygen species) scavenging properties, are widely used in industry, medical research and plant science $[13,14]$. Cerium oxide nanoparticles were reported to reduce overaccumulated ROS, thus improving plant tolerance to stress such as salinity $[15,16]$ light and temperature stress [16]. Further studies showed that after scavening of ROS, nanoceria could modulate the activities of channel proteins related to $\mathrm{K}^{+}$efflux to enable better mesophyll $\mathrm{K}^{+}$retention, and upregulate the expression of $H K T 1$ gene to allow better shoot $\mathrm{Na}^{+}$exclusion, thus improving plant salt tolerance $[17,18]$. To our surprise, to date, no PNC nanopriming was tested on rapeseeds. Whehter PNC nanopriming would improve rapeseed salt tolerance is still unknown. Also, the mechanisms underlying PNC nanopriming improved plant salt tolerance are ambigous. Our previous study showed that under paperoll condition, PNC nanopriming improved salt tolerance in cotton seedlings by modulating ROS homeostasis and $\mathrm{Ca}^{2+}$ signalling [19]. However, whether the underlying mechanisms such as nanoparticle distribution in PNC primed seeds, and the maintanence of ROS homeostasis and $\mathrm{Na}^{+} / \mathrm{K}^{+}$ratio in the consequent established seedlings will be different between rapeseed and other crops e.g. cotton are still unknown. Also, the effect of PNC nanopriming on the relative gene expression level and activities of a-amylase and thus the solube sugar content in seeds during the priming hours was largely overlooked. In the present study we will try to address above questions to investigate the mechanisms regarding PNC nanopriming improved plant salt tolerance.

In this work, we studied the distribution of PNC in the seed coat, cotyledon, and radical during the priming hours. We analyzed the activities and relative gene expression of a-amylase in rapeseeds with PNC nanopriming. Furthermore, after priming, we compared the activities of antioxidant enzymes and the ROS level between PNC nanoprimed rapeseeds and the control one under salinity stress. We also investigated the $\mathrm{Na}^{+}$content, $\mathrm{K}^{+}$content, and $\mathrm{Na}^{+} / \mathrm{K}^{+}$ratio in shoot and root in salt $(200 \mathrm{mM} \mathrm{NaCl})$ stressed rapeseeds with or without PNC nanopriming. Our results add more knowledge to nanopriming improved plant salt tolerance. 


\section{Materials And Methods}

\section{Synthesis and characterization of nanoceria (PNC)}

Following our previous paper [20] , $1.08 \mathrm{~g}$ of cerium (III) nitrate (Sigma Aldrich, $99 \%$ ) and $4.5 \mathrm{~g}$ poly

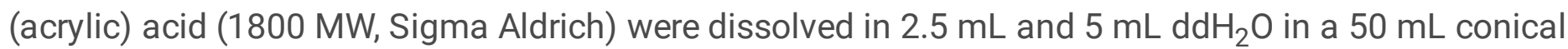
tube, respectively. These solutions were thoroughly mixed by using a vortex mixture at 2,000 rpm for 15 minutes. To a $50 \mathrm{~mL}$ glass beaker, $15 \mathrm{~mL}$ of $30 \%$ ammonium hydroxide solution (Sigma Aldrich) (7.2 M) was added. The mixture of cerium (III) nitrate and poly (acrylic) acid was added dropwise into the ammonium hydroxide solution while stirring at $500 \mathrm{rpm}$ overnight at room temperature in a fume hood. After $24 \mathrm{~h}$, to remove any possible debris and large agglomerates, the final solution obtained was transferred to $50 \mathrm{~mL}$ conical tube and centrifuged at 4,000 $\mathrm{xg}$ for $1 \mathrm{~h}$. The obtained supernatant was transferred into three $15 \mathrm{~mL} 10 \mathrm{kDa}$ filters (MWCO $10 \mathrm{~K}$, Millipore Inc.) and centrifuged at 4,500 rpm for at least six cycles (45 min each cycle) for further purification. The freshly synthesized PNC was stored at 4 ${ }^{\circ} \mathrm{C}$ until further use. The final concentration of the synthesized PNC solution was calculated by recording the absorbance at $271 \mathrm{~nm}$ using an UV-VIS spectrophotometer according to Beer-Lambert's law (Figure S1). The zeta potential and size of PNC dispersed in DI water were measured by dynamic light scattering instrument (Malvern Zetasizer, Nano). FEI Talos microscope operating at $300 \mathrm{kV}$ was used for recording transmission electron microscopy (TEM) images.

\section{Seed materials, seed priming, stress treatments, and growth conditions}

Seeds of rapeseed salt-sensitive variety "Zhongshuang 11" (ZS 11) were used in this experiment [21]. After concentration screening experiment (Figure S2), $0.1 \mathrm{mM} \mathrm{PNC}$ was used as a priming agent in this experiment. For $\mathrm{pH}$ maintenance, $\mathrm{PNC}$ in $10 \mathrm{mM}$ TES buffer (pH 7.5 adjusted by $\mathrm{HCl}$ ) [20] was used. 10 mM TES buffer alone was used as a control group. Seeds were immersed in PNC+TES or TES solution. The conical flasks containing the seeds and priming solution were put on a mechanical shaker (50 rpm) under dark conditions with constant gentle agitation for 8 hours, and the seed to solution ratio was 1:5 $(\mathrm{w} / \mathrm{v})$ [1]. After $8 \mathrm{~h}$ priming, the seeds were rinsed with DI water and the seeds were kept in dark at ambient room temperature to dry-back. The primed seeds were sown in polyethylene boxes $(12 \times 12 \times 6 \mathrm{~cm}$ length, breadth, and height, respectively). The boxes contained three sterilized germination papers moistened with $10 \mathrm{~mL}$ of $200 \mathrm{mM} \mathrm{NaCl}$ solution or DI water. Every second day the bottom two germination papers were replaced with two new papers and $7 \mathrm{~mL}$ of salt solution or DI water was added to the corresponding boxes. The boxes were exposed to $14 \mathrm{~h}$ light $\left(200 \mu \mathrm{mol} \mathrm{m} \mathrm{m}^{-2} \mathrm{~s}^{-1}\right)$ and $10 \mathrm{~h}$ dark duration with $25 \pm 1$ and $20 \pm 1{ }^{\circ} \mathrm{C}$, respectively. The germination rate was recorded on daily basis and the germination trail was terminated 7 days after sowing. Then, the biomass was recorded immediately.

\section{Localization of nanoceria in rapeseed seeds}

To visualize the localization of nanoceria in the different tissues of seed, i.e. seed coat, cotyledon, and radical, during priming hours, PNC was labeled with 1,1'-dioctadecyl-3,3,3',3'-tetramethylindocarbocyanine perchlorate (Dil) fluorescent dye following the standard protocols as described in previous 
study [20]. Briefly, $4 \mathrm{~mL}$ of $0.5 \mathrm{mM}(5.8 \mathrm{mg} / \mathrm{L}) \mathrm{PNC}$ was mixed with $200 \mu \mathrm{L}$ Dil dye solution [0.3 mg/L, in dimethylsulfoxide (DMSO)] at 1,000 rpm continuous stirring for $1 \mathrm{~min}$ at ambient temperature. The obtained mixture was then purified at 4,500 rpm for five cycles ( 5 min each cycle) using a $10 \mathrm{~K}$ Amicon cell (MWCO 30K, Millipore Inc.). Eventually, final concentration of Dil-PNC solution was calculated using the same method as described in section 2.1 (Figure S1).

Rapeseed seeds were immersed in the Dil-PNC+TES solution for the 1, 3, and 8 hours with TES (10 mM) as a control group. At each time point, the seeds were sliced into seed coat, cotyledon, and radical ( 200 $\mu \mathrm{m}$ size). The sliced seed tissues at different time points were mounted on the glass sides. A drop of perfluorodecalin (PFD) was applied to each slice for better quality of confocal imaging. A square coverslip was placed on the mounted sample and was gently pressed to well-cover the sample with observation gel and remove the air bubbles trapped underneath. The prepared sample slide was placed on the microscope and imaged by a Leica laser scanning confocal microscope (TCS, SP8). The imaging settings are as follows: $514 \mathrm{~nm}$ laser excitation; Z-Stack section thickness: $4 \mu \mathrm{m}$; PMT1, 550-615 nm, for Dil-PNC fluorescence; PMT2, 700-750 nm, for the possible fluorescence of different seed tissues. 3-4 biological replicates were used for confocal imaging.

\section{Measurement of a-amylase activity, water content, and total soluble sugar content in rapeseeds}

For the imbibition experiments, $0.5 \mathrm{~g}$ seeds were immersed in the respective solutions. The water absorbance by the seeds was calculated from difference in initial weight and the water absorbed during the particular hour of priming. The activity of a-amylase was determined by 3, 5-dinitrosalicylic acid (DNS) method [22]. For each treatment, $1 \mathrm{~g}$ seeds was grinded in liquid nitrogen with the help of mortar and pestle. The grinded samples were transferred into centrifuge tubes containing $10 \mathrm{~mL}$ of phosphate buffer ( $\mathrm{pH}$ 7). Pipetted $100 \mu \mathrm{L}$ enzyme solution into tubes containing $1 \mathrm{~mL}$ DNS reagents and $1 \mathrm{~mL}$ distilled water. All the tubes were incubated in hot water bath for 10 minutes, and then were allowed to cool down at ambient temperature. Finally, the samples were well-mixed and the absorbance was recorded at $540 \mathrm{~nm}$ while tarring the spectrophotometer with a blank sample. The total soluble sugar content was determined by following the instructions provided by Suzhou Biotechnology Co., Ltd. "Kit for total soluble sugar determination" (item number: G0501W).

\section{Quantification of ROS levels and antioxidants enzymes assay}

For the determination of hydrogen peroxide $\left(\mathrm{H}_{2} \mathrm{O}_{2}\right)$ and superoxide anion $\left({ }^{\circ} \mathrm{O}_{2}{ }^{-}\right)$assay, kits from "Nanjing Jiancheng Biotechnology Co., Ltd (item number: A04-1-1)" and “Beijing Leigen Biotechnology Co., Ltd. (item number: T01123)" were used respectively. $\mathrm{H}_{2} \mathrm{O}_{2}$ and ${ }^{\circ} \mathrm{O}_{2}{ }^{-}$contents were measured according to the instructions provided by the manufacturer. MDA content was determined by homogenizing $0.1 \mathrm{~g}$ fresh sample with $1 \mathrm{~mL}$ of $5 \%(\mathrm{w} / \mathrm{v})$ tricholoroacetic acid at $10,000 \mathrm{~g}$ for $10 \mathrm{~min}$ [23]. Subsequently, $0.4 \mathrm{~mL}$ of $5 \%$ of trcichloroacetic acid (TTCA) containing $0.67 \%(\mathrm{w} / \mathrm{v})$ thiobarbituric acid (TBA) was added to $0.4 \mathrm{~mL}$ of the supernatant. The absorbance was recorded via spectrophotometer at $450 \mathrm{~nm}, 532 \mathrm{~nm}$, and 600 $\mathrm{nm}$. MDA was quantified as follow: MDA concentration $(\mu \mathrm{mol} / \mathrm{L})=6.45(\mathrm{~A} 532-\mathrm{A} 600)-0.56 \mathrm{~A} 450$, where $\mathrm{A}=$ 
absorbance at different wavelengths. Finally, MDA content $(\mu \mathrm{mol} / \mathrm{g})=\mathrm{C} \times \mathrm{V} /(1000 \times \mathrm{W}), \mathrm{C}=$ concentration of MDA, $\mathrm{V}=$ sample extraction liquid $(\mathrm{mL}), \mathrm{W}=$ weight of sample.

The activities of superoxide dismutase (SOD) was measured by homogenizing $0.1 \mathrm{~g}$ fresh sample in 1 $\mathrm{mL}$ of phosphate buffer ( $\mathrm{pH} 7.8$ ) having $0.1 \mathrm{mM}$ EDTA [24]. The homogenate was centrifuged at 12,000 rpm at $4{ }^{\circ} \mathrm{C}$. In a $10 \mathrm{~mL}$ tube, $0.2 \mathrm{ml}$ of the enzyme extract, $0.3 \mathrm{~mL} 130 \mathrm{mmol} / \mathrm{L}$ Met (methionine) buffer, $0.3 \mathrm{~mL} 750 \mu \mathrm{mol} / \mathrm{L} \mathrm{NBT}$ (nitroblue tetrazolium), $0.3 \mathrm{~mL} 100 \mu \mathrm{mol} / \mathrm{L} \mathrm{EDTA-Na}{ }_{2}$, and $0.3 \mathrm{ml}$ of $20 \mu \mathrm{mol} / \mathrm{L}$ flavin were added. At the end of the reaction, dark control tube was used as a blank control, and the absorbance was recorded at $560 \mathrm{~nm}$ using spectrophotometer. SOD activity $(\mathrm{U} / \mathrm{g})=2(\mathrm{ACK}-\mathrm{AE}) \times \mathrm{V} /(\mathrm{ACK}$ $\times \mathrm{W} \times \mathrm{Vt}), \mathrm{ACK}=$ dark control absorbance, $\mathrm{AE}=$ sample absorbance, $\mathrm{V}=$ volume of sample $(\mathrm{mL}), \mathrm{W}=$ weight of sample $(\mathrm{g}), \mathrm{Vt}=$ extract liquid volume $(\mathrm{mL})$. The catalase (CAT) activity was measured according to the standard procedures of [25]. Samples were ground with PBS buffer (pH 7.8) followed by centrifugation at 4,000 rpm (15 min). After the centrifugation the collected supernatant was vortexed with PBS buffer ( $\mathrm{pH} 7.8)$ and $\mathrm{H}_{2} \mathrm{O}_{2}(10 \mathrm{mM})$. At $240 \mathrm{~nm}$ (1 record/ $\left.1 \mathrm{~min}, 4 \mathrm{~min}\right)$, the average decrease in the absorbance was recoded and the absorbance coefficient of $43.6 \mathrm{M}^{-1} \mathrm{~cm}^{-1}$ was used. The final value of CAT was expressed as $\mathrm{mmol} \mathrm{H}_{2} \mathrm{O}_{2} / \mathrm{mg}$ protein/min. Peroxidase (POD) activity was determined using guaiacol method [23]. The reaction mixture was comprised of $10 \mathrm{mM}$ guaiacol, $5 \mathrm{mM} \mathrm{H}_{2} \mathrm{O}_{2}$ in $50 \mathrm{mM}$ phosphate buffer $\left(\mathrm{pH} \mathrm{7.0)}\right.$ ) heated at $25^{\circ} \mathrm{C}$. in $10 \mathrm{~mL}$ tube, $0.2 \mathrm{~mL}$ enzyme extract and $2.8 \mathrm{~mL}$ of the reaction mixture was added and mixed subsequently while the absorbance was recorded at $470 \mathrm{~nm}$. Using the absorbance coefficient of $26.6 \mathrm{mM}^{-1} \mathrm{~cm}^{-1}$, the POD activity was calculated via analyzing the averaged decrease of the recorded absorbance value at $470 \mathrm{~nm}$ ( 1 record/1 $\mathrm{min}, 3 \mathrm{~min}$ ). The final value of POD was expressed as $\mu \mathrm{mol}$ tetra-gualacol $/ \mathrm{mg}$ protein $/ \mathrm{min}$.

\section{RNA isolation and quantitative real-time PCR (qRT-PCR) analysis}

RNAprep Pure Plant Kit (RN38, Aidlab, Beijing, China) was used for the total RNA isolation. Using the TRUEscript first Strand cDNA Synthesis Kit (PC5402, Aidlab, Beijing, China), $2 \mu \mathrm{g}$ of total RNA was reverse transcribed into cDNA. According to the manufacturer's instructions, the amplification of qRT-PCR products was performed in a reaction mixture of $12.5 \mu \mathrm{L}$ SYBR Green qPCR Mix (PC3302, Aidlab, Beijing, China). The qRT-PCR analysis was performed on the Bio-Rad CFX Connect Real-Time PCR System (BioRad, California, USA). For each treatment, three technical and three biological replicates were used. Relative gene expression was calculated using the $2^{-\Delta \Delta \mathrm{Ct}}$ method. The primers used for qRT-PCR are shown in Table S1[26].

\section{Statistical analysis}

Means were compared using a one-way ANOVA based on Tukey and Duncan test in SPSS software. Different lowercase alphabets indictate significant difference at $P=0.05$. Error bars are standard error. The graphs were ploted with Excel 2016.

\section{Results}




\section{Characterization of PNC}

A clear peak at $271 \mathrm{~nm}$ was observed in the absorbance curve of PNC (Figure S1). The images from transmission electron microscopy (TEM) shows an average PNC core size of $4.7 \pm 0.9 \mathrm{~nm}$ (Figure 1a). Analysis from a dynamic light scattering instrument (Malvern Zetasizer, Nano) showed that the average size of PNC by intensity was $8.5 \pm 0.2 \mathrm{~nm}$ (Figure 1b), and the average zeta potential was $-43.3 \pm 6.3 \mathrm{mV}$ (Figure 1c).

\section{Influence of PNC priming on rapeseed germination and phenotype}

The germination rate of rapeseed was not significantly affected by PNC+TES priming under normal growing conditions as compared to TES (or control) priming (Figure 1d). However, a significant difference of the germination rate was observed between PNC+TES priming and the control/TES priming under 200 $\mathrm{mM}$ salinity stress from Day2 to Day7 (trail terminated), showing the final germination rate for PNC priming (84\%) and TES priming $(76 \%)(P<0.05)$. Compared with the TES priming, PNC+TES priming markedly increased fresh weight ( $54.4 \pm 0.3 \mathrm{vs} 34.4 \pm 0.7 \mathrm{mg} /$ seedling, $41 \%$ increase) of the rapeseed seedlings under salt stress (Figure 1e).

\section{Localization of PNC in seeds during priming hours}

Seeds primed with Dil-PNC in $10 \mu \mathrm{M}$ TES buffer for one, three, and eight hours was sampled for visualizing the distribution of PNC in seed coat, cotyledon and radical. The sampling hours $(1 \mathrm{~h}, 3 \mathrm{~h}$, and $8 \mathrm{~h}$ ) were based on a preliminary experiment in which we measured the water absorbance by seeds. $\mathrm{A}$ clear increase of water content was observed in rapeseed seeds during priming hours, showing a sharp increase from $1 \mathrm{~h}$ to $3 \mathrm{~h}$, and a steady increase from $4 \mathrm{~h}$ to $8 \mathrm{~h}$ (Figure $1 \mathrm{f}$ ). The results indicated that the seed begins to absorb water from the first hour of priming, whereas the peak difference in water absorbance was recorded at $3 \mathrm{~h}$ and $8 \mathrm{~h}$. PNC priming enabled better water absorbance in seeds than the control at 1, 3 and 8 hours (Figure 1g). During the first hour of priming, Dil-PNC signal was only detected in the seed coat (Figure 2a), compared with no Dil-PNC signals were detected in cotyledon (Figure 2b) and radical (Figure 2c). At 3h priming, Dil-PNC signal was observed in both the seed coat (Figure 2a) and cotyledon (Figure 2b), while no Dil-PNC signal was detected in radical (Figure 2c). Further, during $8 \mathrm{~h}$ priming, Dil-PNC was found in all tissues of the seed, i.e., seed coat, cotyledon, and radical, showing the signal intensity as seed coat > cotyledon > radical (Figure 2a, b, and c). No signals were detected in the control group at $1 \mathrm{~h}, 3 \mathrm{~h}$, and $8 \mathrm{~h}$ priming (Supplementary Figure S3-5).

\section{PNC nanopriming regulated relative expression of $A M Y$ genes to enhance a-amylase activity and total soluble sugar content in rapeseeds}

Significant differences in a-amylase activity were recorded during the priming hours of PNC priming $(P<$ 0.05). Seed priming with PNC+TES increased a-amylase activity by $175 \%, 309 \%$, and $295 \%$ at $1 \mathrm{~h}(0.130 \pm$ 0.038 vs $\left.0.047 \pm 0.003 \mathrm{mg} \mathrm{g}^{-1} \mathrm{~min}^{-1}\right)$, 3h $\left(0.341 \pm 0.005\right.$ vs $\left.0.0883 \pm 0.001 \mathrm{mg} \mathrm{g}^{-1} \mathrm{~min}^{-1}\right)$, and $8 \mathrm{~h}$ $\left(0.357 \pm 0.048\right.$ vs $\left.0.090 \pm 0.002 \mathrm{mg} \mathrm{g}^{-1} \mathrm{~min}^{-1}\right)$ priming, respectively, compared to the TES priming 
control (Figure 3a). Consistently, at $1 \mathrm{~h}$ and $8 \mathrm{~h}$, the relative expression level for $A M Y 1$ gene was significantly higher in PNC+TES primed seeds than the TES priming control, while a downregulation of $A M Y 1$ gene was found at $3 \mathrm{~h}$ (Figure $3 \mathrm{~b}$ ). The upregulation of $A M Y 2 \mathrm{gene}$ was found at $8 \mathrm{~h}$ priming with $\mathrm{PNC}+\mathrm{TES}$ than the TES control, compared with no difference at 1 and $3 \mathrm{~h}$ priming (Figure 3c). The highest increase in the relative expression values for $A M Y 1$ and $A M Y 2$ was recorded at $8 \mathrm{~h}$ priming, showing $169 \%$ and $68 \%$ increase respectively (Figure $3 \mathrm{~b}$ and $3 \mathrm{c}$ ). Compared to TES priming, PNC+TES priming significantly increased total soluble sugar content (TSS) by $177 \%, 64 \%$, and $58 \%$ during $1 \mathrm{~h}$ ( $8.8 \pm 0.1$ vs $\left.3.2 \pm 0.2 \mathrm{mg} \mathrm{g}^{-1} \mathrm{FW}\right), 3 \mathrm{~h}\left(10.4 \pm 0.2\right.$ vs $\left.6.4 \pm 0.2 \mathrm{mg} \mathrm{g}^{-1} \mathrm{FW}\right)$, and $8 \mathrm{~h}\left(13.1 \pm 0.2\right.$ vs $\left.8.3 \pm 0.2 \mathrm{mg} \mathrm{g}^{-1} \mathrm{FW}\right)$, respectively (Figure $3 \mathrm{~d}$ ). This is in accordance with the increased activities of a-amylase in PNC+TES primed seeds than the TES control.

\section{PNC nanopriming modulates ROS level in the seeds and seedlings of rapeseeds}

During the first-hour, compared to TES priming, PNC priming showed significantly increased MDA contents ( $2555 \pm 206$ vs $\left.2228 \pm 39 \mathrm{mg} \mathrm{g}^{-1} \mathrm{FW}\right), \mathrm{H}_{2} \mathrm{O}_{2}\left(18.2 \pm 1.3\right.$ vs $14.2 \pm 0.2 \mu \mathrm{mol} \mathrm{g}^{-1} \mathrm{FW}$ ), and ${ }^{\circ} \mathrm{O}_{2}$ - (22.3 \pm 0.3 vs $19.1 \pm 0.3 \mu \mathrm{mol} \mathrm{g}^{-1} \mathrm{FW}$ ) by $15 \%, 28 \%$, and $15 \%$, respectively (Figure $4 \mathrm{a}-\mathrm{c}$ ). Whereas, at $3 \mathrm{~h}$ and $8 \mathrm{~h}, \mathrm{PNC}$ priming reduced the ROS contents. At $3 \mathrm{~h}, \mathrm{PNC}$ priming significantly reduced MDA contents (1428 \pm 156 vs $\left.1849 \pm 132 \mathrm{mg} \mathrm{g}^{-1} \mathrm{FW}\right), \mathrm{H}_{2} \mathrm{O}_{2}\left(7.3 \pm 0.1\right.$ vs $\left.10.5 \pm 0.5 \mu \mathrm{mol} \mathrm{g}^{-1} \mathrm{FW}\right)$, and ${ }^{\circ} \mathrm{O}_{2}^{-}(9.3 \pm 0.4$ vs $18.1 \pm 0.3 \mu \mathrm{mol} \mathrm{g}^{-1} \mathrm{FW}$ ) by $23 \%, 31 \%$, and $48 \%$ than the TES priming, respectively (Figure $4 \mathrm{a}-\mathrm{c}$ ). Similarly, at $8 \mathrm{~h}$, the MDA contents ( $1144 \pm 14$ vs $1625 \pm 156 \mathrm{mg} \mathrm{g}^{-1} \mathrm{FW}, 30 \%$ decrease), $\mathrm{H}_{2} \mathrm{O}_{2}(3.0 \pm 0.1$ vs $10 \pm 0.3 \mu \mathrm{mol} \mathrm{g}{ }^{-1} \mathrm{FW}, 70 \%$ decrease), and ${ }^{\circ} \mathrm{O}_{2}{ }^{-}\left(5.2 \pm 0.2\right.$ vs $14.1 \pm 0.3 \mu \mathrm{mol} \mathrm{g}^{-1} \mathrm{FW}, 64 \%$ decrease) was significantly lower in PNC+TES primed seeds than the TES control (Figure 4a-c). A significant increase of SOD and POD activities was found in seeds primed with PNC+TES than the TES control (Figure $4 \mathrm{~d}$ and $4 \mathrm{e}$ ). PNC priming increased SOD activities in seeds than the control by $52 \%, 127 \%$, and $53 \%$ at $1 \mathrm{~h}\left(92.6 \pm 1.3\right.$ vs $\left.60.8 \pm 1.3 \mathrm{Ug}^{-1} \mathrm{FW}\right), 3 \mathrm{~h}\left(156.2 \pm 1.3\right.$ vs $\left.68.7 \pm 1.3 \mathrm{U} \mathrm{g}^{-1} \mathrm{FW}\right)$, and $8 \mathrm{~h}(172.1 \pm$ 1.3 vs $112.5 \pm 1.3 \mathrm{U} \mathrm{g}^{-1} \mathrm{FW}$ ), respectively (Figure 4d). PNC priming increased POD activities in seeds than the control by $76 \%$ and $53 \%$ and $60 \%$ at $1 \mathrm{~h}(6.4 \pm 1.0 \mathrm{vs} 3.6 \pm 0.1 \mu \mathrm{mol}$ tetra-gualacol $/ \mathrm{mg}$ protein $/ \mathrm{min})$, $3 \mathrm{~h}(5.9 \pm 0.4 \mathrm{vs} 3.8 \pm 0.1 \mu \mathrm{mol}$ tetra-gualacol $/ \mathrm{mg}$ protein $/ \mathrm{min})$ and $8 \mathrm{~h}(7.1 \pm 0.3$ vs $4.5 \pm 0.1 \mu \mathrm{mol}$ tetragualacol /mg protein/min), respectively (Figure 4e). In contrast to the changes of SOD and POD activities, PNC priming resulted significantly lower CAT activity in seeds than the control, showing $43 \%$ and $55 \%$ decrease at $3 \mathrm{~h}\left(0.85 \pm 0.07\right.$ vs $1.49 \pm 0.09 \mathrm{mmol} \mathrm{H}_{2} \mathrm{O}_{2} / \mathrm{mg}$ protein/min), and $8 \mathrm{~h}(0.84 \pm 0.07$ vs $1.88 \pm$ $0.15 \mathrm{mmol} \mathrm{H} \mathrm{O}_{2} / \mathrm{mg}$ protein/min), respectively (Figure $4 \mathrm{f}$ ).

Compared with the non-stress condition, $\mathrm{MDA}, \mathrm{H}_{2} \mathrm{O}_{2}$, and ${ }^{\circ} \mathrm{O}_{2}{ }^{-}$contents were significantly increased in salt stressed (200 mM NaCl, 7 days) seedlings of rapeseeds with or without PNC priming (Figure 5a-e). Under non-saline condition, no difference of $\mathrm{MDA}, \mathrm{H}_{2} \mathrm{O}_{2}$, and ${ }^{\circ} \mathrm{O}_{2}{ }^{-}$content was found in either shoot or root seedlings of rapeseeds (7 days old) with or without PNC priming. However, under salt stress, PNC primed seedlings significantly reduced MDA (5234 \pm 165 vs $6918 \pm 100 \mathrm{mg} \mathrm{g}^{-1} \mathrm{FW}, 24 \%$ decrease), $\mathrm{H}_{2} \mathrm{O}_{2}$ (23.4 \pm 0.6 vs $69.8 \pm 1.8 \mu \mathrm{mol} \mathrm{g}^{-1} \mathrm{FW}, 66 \%$ decrease), and ${ }^{\circ} \mathrm{O}_{2}{ }^{-}\left(3.4 \pm 0.3\right.$ vs $6.7 \pm 0.3 \mu \mathrm{mol} \mathrm{g}^{-1} \mathrm{FW}, 50 \%$ 
decrease) content in shoot than the control (Figure a, $5 \mathrm{c}$ and $5 \mathrm{e}$ ). Similarly, compared with the control, $27 \%, 39 \%$, and $37 \%$ decrease of MDA (3395 \pm 47 vs $\left.4656 \pm 122 \mathrm{mg} \mathrm{g}^{-1} \mathrm{FW}\right), \mathrm{H}_{2} \mathrm{O}_{2}$ (13.2 \pm 0.7 vs $21.6 \pm$ $1.6 \mu \mathrm{mol} \mathrm{g}{ }^{-1} \mathrm{FW}$ ), and ${ }^{\circ} \mathrm{O}_{2}^{-}\left(6.1 \pm 0.7 \mathrm{vs} 9.7 \pm 1.8 \mu \mathrm{mol} \mathrm{g}{ }^{-1} \mathrm{FW}\right)$ content was found in the root of PNC primed seedlings (Figure $5 b, 5 d$ and $5 f$ ). Similar to the results of the seeds during priming hours, compared with a decrease in CAT activities $\left(0.94 \pm 0.05 \mathrm{vs} 1.78 \pm 0.03 \mu \mathrm{mol} \mathrm{H}_{2} \mathrm{O}_{2} / \mathrm{mg}\right.$ protein $/ \mathrm{min}$ for shoot, and $1.10 \pm 0.02$ vs $1.60 \pm 0.02 \mu \mathrm{mol} \mathrm{H}_{2} \mathrm{O}_{2} / \mathrm{mg}$ protein/min for root), a significant increase of SOD (183.9 \pm 6.6 vs $151.3 \pm 8.2 \mathrm{U} \mathrm{g}^{-1} \mathrm{FW}$ for shoot, and $131.7 \pm 1.2$ vs $107.6 \pm 5.7 \mathrm{U} \mathrm{g}^{-1} \mathrm{FW}$ for root) and POD (6.5 \pm 0.6 vs $5.53 \pm 0.05 \mu \mathrm{mol}$ tetra-gualacol $/ \mathrm{mg}$ protein $/ \mathrm{min}$ for shoot, and $8.8 \pm 0.3$ vs $5.6 \pm 0.2$ $\mu \mathrm{mol}$ tetra-gualacol /mg protein /min for root) activities was found in shoot and root of seedlings primed with PNC+TES than the TES control under salt stress (Figure 6a-e). Under non-saline condition, no significant difference was found between seedlings primed with and without PNC priming (Figure 6a-e). It shows that PNC priming enhanced shoot and root SOD (21\% and $22 \%$, respectively) and POD (17\% and $49 \%$, respectively) activities in contrast to the control under salt stress conditions (Figure 6a-d), while a decrease of CAT activity by $82 \%$ and $31 \%$ was observed in the shoot and root compared to the control under salt stress (Figure 6e-f).

\section{PNC nanopriming affected $\mathrm{Na}^{+} / \mathrm{K}^{+}$ratio in rapeseed under salt stress}

Compared to non-saline conditions, an increase of $\mathrm{Na}^{+}$content was found in salt stressed $(200 \mathrm{mM} \mathrm{NaCl}$, 7 days) seedlings of rapeseeds with or without PNC priming (Figure 7a-b). However, seedlings with PNC priming showed increased shoot $\mathrm{Na}^{+}$content by $13 \%\left(17.5 \pm 0.4\right.$ vs $15.6 \pm 0.7 \mathrm{mg} \mathrm{g}^{-1} \mathrm{DW}$, Figure $\left.7 \mathrm{a}\right)$ and decreased root $\mathrm{Na}^{+}$content by $52 \%\left(7.0 \pm 0.5 \mathrm{vs} 14.5 \pm 0.6 \mathrm{mg} \mathrm{g}^{-1} \mathrm{DW}\right.$, Figure $\left.7 \mathrm{~b}\right)$ than the control under salt stress. An overall decrease of $\mathrm{Na}^{+}$content was observed in seedlings primed with PNC than the control under salt stress ( $24.5 \pm 0.6$ vs $30.8 \pm 0.6 \mathrm{mg} \mathrm{g}^{-1} \mathrm{DW}$, Figure S6a). In comparison with non-saline conditions, $\mathrm{K}^{+}$content in shoot and root of seedlings with or without PNC priming was significantly reduced under salt stress (200 mM NaCl, 7 days) (Figure 7c and 7d). While seedlings primed with PNC maintained higher $\mathrm{K}^{+}$content in the shoot and root by $31 \%$ (3.80 \pm 0.06 vs $2.91 \pm 0.27 \mathrm{mg} \mathrm{g}^{-1}$ DW, Figure 7c) and $29 \%$ ( $2.9 \pm 0.2$ vs $2.3 \pm 0.1 \mathrm{mg} \mathrm{g}^{-1} \mathrm{DW}$, Figure $\left.7 \mathrm{~d}\right)$, respectively than the control (seedlings primed with TES) under salt stress. An overall better maintained $\mathrm{K}^{+}$content was observed in seedlings primed with PNC than the control under salt stress ( $6.7 \pm 0.2$ vs $5.1 \pm 0.2 \mathrm{mg} \mathrm{g}^{-1} \mathrm{DW}$, Figure S6b). Not surprisingly, compared to the TES control, seedlings primed with PNC showed significantly reduced $\mathrm{Na}^{+} / \mathrm{K}^{+}$ratio by $10 \%$ and $62 \%$ in the shoot $(4.6 \pm 0.2$ vs $5.1 \pm 0.2$, Figure $7 \mathrm{e})$ and root $(2.4 \pm 0.2$ vs $6.3 \pm$ 0.2 , Figure 7f) under salinity stress, respectively. An overall decreased $\mathrm{Na}^{+} / \mathrm{K}^{+}$ratio was observed in seedlings primed with PNC than the control under salt stress ( $3.65 \pm 0.07$ vs $5.81 \pm 0.08$, Figure S6c). No significant difference of $\mathrm{Na}^{+} / \mathrm{K}^{+}$ratio in either shoot or root was found in seedlings primed with and without PNC under non-saline condition (Figure 7e and 7f).

\section{Discussion}




\section{PNC nanopriming improves rapeseed salt tolerance through modulating a-amylase activity}

In terms of nano-enabled agriculture, nanopriming technique could be a good candidate to improve plant tolerance to salinity stress. In wheat, seed priming with silver nanoparticles (AgNPs) improved the germination and growth parameters by regulating hormonal balance and photosynthetic efficiency under salt stress [27]. Under salt stress, nanopriming with calcium silicate $\left(\mathrm{Ca}_{2} \mathrm{SiO}_{4}\right)$ in lettuce improved seed germination through triggering antioxidant enzymes including SOD, CAT and GR (glutathione reductase) to effectively scavenge the over-produced ROS [28]. Water soluble carbon nanoparticles (CNPS) promoted lettuce germination and lateral root growth under salt stress [29]. Titanium dioxide $\left(\mathrm{TiO}_{2}\right)$ nanopriming positively affected germination and seedling growth under salt stress by promoting antioxidant enzymes, relative water content, proline content, $\mathrm{K}^{+}$content, and reduced $\mathrm{Na}^{+}$content in maize crop [18]. Compared with the water control, soaking cotton seeds with nanoceria showed increased tolerance $(46 \%$ increase of fresh weight) to salt stress, whereas no significant difference of germination rate was found between the treatments [19]. During the imbibition of water, nanoparticles enters the seed via the void spaces in the seed coat while some nanoparticles may also tend to adsorb at the surface of seed coat [30]. However, the surface adsorptions of the nanoparticles at seed coat may pose negative effects on germination, seedling growth, and enzymatic activities [31]. Here, we show that during priming hours, most of PNC is located at the surface of seed coat (Fig. 2), indicating a possible interaction between PNC and seed coat which might benefit seed performance under salt stress. PNC nanopriming significantly improved rapeseed tolerance to salinity stress, showing not only the increase of germination rate (12\%) but also the fresh weight $(41 \%)$ in rapeseed primed with PNC + TES than the TES buffer under salt stress (Fig. 1d and 1e). Our results showed that PNC nanopriming could help to improve salt tolerance in rapeseeds.

Generally, seed germination begins with imbibition (water uptake by seed) and terminates with the protrusion of radicle and plumule through the seed envelope [32]. During the germination, a-amylase is the key enzyme responsible for the degradation of starch [33]. Thus, under stress conditions the enhancement of a-amylase activity during the priming hours is associated with plant stress tolerance [34-36]. The results of our experiment revealed that PNC priming showed increased a-amylase activity than the control during $1 \mathrm{~h}, 3 \mathrm{~h}$, and $8 \mathrm{~h}$ priming hours, which is further confirmed by the upregulation of relative gene expression of $A M Y 1$ and $A M Y 2$ in PNC + TES primed seeds than the TES priming (Fig. 3). Interestingly, we noticed that at $3 \mathrm{~h}$ priming, no upregulation of $A M Y 1$ and $A M Y 2$ was observed in PNC primed seeds than the control, while the a-amylase activity is increased in PNC group (Fig. 3), showing that the a-amylase activity could not be fully reflected by the relative expression of a-amylase genes (AMY1 and AMY2 in this study). This could be due to posttranscriptional regulation on a-amylase [37] or some other factors which could affect the activities of a-amylase. Another reason of the enhanced aamylase activity in PNC + TES primed seeds might be associated with higher uptake of water during the imbibition period (Fig. 1g). During seed priming, higher amount absorbed water is always associated with the increased total soluble sugars [38]. Not surprisingly, significant higher content of total soluble sugars was found in rapeseed seeds primed with PNC + TES than TES alone, further supporting the higher a- 
amylase activity in PNC primed seeds (Fig. 3a). This is similar to previous studies showing that nanopriming enhanced a-amylase activity and enhanced soluble sugar content to improve seed germination [33]. The amount of available soluble sugars in seeds are of importance for the following buildup of seedlings and even its stress tolerance [39]. Previous studies showed nanopriming [Zinc oxide (ZnO-NPs) nanoparticles, $50 \mathrm{ppm}, 50 \mathrm{~nm}, 23 \mathrm{mV}$ ] enabled a positive correlation between improved aamylase activity and seed germination and seedling vigor of lettuce plants [40]. Researchers found that seeds with higher amount of total soluble sugars showed better performance in seedling buildup and also the tolerance to drought stress [39]. Overall, our results showed that in rapeseeds, PNC nanopriming upregulated the relative expression of $A M Y 1$ gene, showing increased a-amylase activity and thus significant higher total soluble sugar content than the control (TES priming). It then enabled better establishment of seedlings and also its tolerance to salinity stress in rapeseed primed with PNC + TES than TES priming.

\section{PNC nanopriming reduces ROS over-accumulation to maintain better $\mathrm{Na}^{+} / \mathrm{K}^{+}$ratio homeostasis to improve rapeseed salt tolerance}

ROS accumulation is always observed in primed seeds [30]. While over-accumulation of ROS could induce toxic effects to plants $[17,19]$. PNC are known as potent ROS scavenger. Here, compared with higher ROS $\left(\mathrm{H}_{2} \mathrm{O}_{2},{ }^{\circ} \mathrm{O}_{2}{ }^{-}\right)$and MDA content in PNC + TES treated seeds than the TES group during $1 \mathrm{~h}$ priming, PNC + TES treatment significantly reduced the over-production of ROS than the TES control in seeds during $3 \mathrm{~h}$ and $8 \mathrm{~h}$ priming (Fig. 4a-c). The higher ROS content in PNC + TES than TES treatment at $1 \mathrm{~h}$ priming could be related to more absorbed water (Fig. 1g) which could trigger ROS accumulation in primed seeds [41, 42]. During priming, cotyledon and radicle are the main source for the accumulated ROS [43-45]. While, at $1 \mathrm{~h}$ priming, PNC were mainly distributed at the seed coat (Fig. 2a-C), thus it might not be able to scavenge the higher amount of accumulated ROS than the control due to the better water absorbance in PNC primed seeds than the control (Fig. 1g). At 3h and 8h priming, PNC were also found in cotyledon and radicle (Fig. 2a-C), which helped to scavenge more the accumulated ROS in primed seeds. More interestingly, the amount of ROS in seeds are reduced alongside the priming hours, while PNC + TES group showed higher reduced amount of ROS than the TES control (Fig. 4b and 4c). Maintenance of ROS homeostasis during seed priming is of importance to seed germination and consequent seedling establishment [46]. Our results suggest that PNC nanopriming could enable better ROS scavenging ability in seeds during the priming hours (except the first hour) than the control.

After $1 \mathrm{~h}$ priming, the activities of antioxidant enzymes are associated with ROS level in seeds, showing a significant higher SOD and POD activities in PNC + TES primed seeds than the TES priming at $3 \mathrm{~h}$ and $8 \mathrm{~h}$ priming (Fig. 4d-e). Similarly, the activity of SOD and POD was reported to increase and thereby controlling the over-production of $\mathrm{H}_{2} \mathrm{O}_{2}$ and ${ }^{\circ} \mathrm{O}_{2}{ }^{-}$radicals in different crops due to nanopriming [47-49]. Nevertheless, in our experiment PNC reduced the activity of CAT during the priming hours (Fig. 4f. The lower activity of CAT in our experiment could be due to the fact that PNC can mimic CAT activity [16]. These findings are strongly supported by former studies which used spectrofluorometric using the 
Amplex-Red reagent assay to confirm nanoceria (PNC) catalase-like catalytic activity [50]. Interestingly, the ROS level and the maintenance of ROS homeostasis showed similar trends between the priming hours experiments and the post-germination experiment. PNC priming significantly reduced the overproduction of ROS $\left(\mathrm{H}_{2} \mathrm{O}_{2}\right.$ and ${ }^{\circ} \mathrm{O}_{2}{ }^{-}$radicals) in the shoot and root of rapeseed seedlings grown under 200 $\mathrm{mM}$ salt stress (Fig. 5a-f), suggesting that PNC nanopriming helped to maintain ROS homeostasis in the consequent established seedlings. Also, in contrary to the lower CAT activities, under salinity stress, SOD and POD activities are higher in rapeseeds seedling originated from PNC primed seeds than the control, regardless of shoot or root (Fig. 6a-f), showing that PNC nanopriming could affect the efficacy of antioxidant enzyme system in established seedlings. This might be associated with possible epigenetic effects enabled by nanomaterials in seeds $[46,51]$. The successful savaging of ROS by PNC under suboptimal growing conditions were also reported by several other studies $[15,17,19,52]$

Besides osmotic stress and ROS over-accumulation, salinity also cause $\mathrm{Na}^{+}$over-accumulation and $\mathrm{K}^{+}$ loss in plants [53-56]. The ability of plants to maintain $\mathrm{Na}^{+}$and $\mathrm{K}^{+}$homeostasis is a critical factor for its salt tolerance [57]. As usual, salt stress increased $\mathrm{Na}^{+}$accumulation in shoot and root; however, PNC priming accumulated more $\mathrm{Na}^{+}$in shoot while less in the root (Fig. 7a-b). This is similar to previous study. $\mathrm{CeO}_{2} \mathrm{NPs}$ allowed more $\mathrm{Na}^{+}$to accumulate in shoot compared to root by decreasing root apoplastic barriers to facilitate $\mathrm{Na}^{+}$transportation to shoot to improve rapeseed salt tolerance [15]. The overall $\mathrm{Na}^{+}$ content in seedlings established from PNC primed seeds is significantly lower than the control under salt stress (Figure S6), suggesting that PNC nanopriming could help to reduce $\mathrm{Na}^{+}$over-accumulation in rapeseed under salt stress. This is different with the effect of nanoceria nanopriming in cotton, which shows that no significant difference of $\mathrm{Na}^{+}$content in cotyledon, hypocotyl and root was found between the seedlings established from nanoceria primed seeds and the control under salt stress [19].

Furthermore, compared with the non-saline condition, salt stress decreased $\mathrm{K}^{+}$content in shoot and root of rapeseed seedlings established with or without PNC nanopriming. Nevertheless, seedlings established from PNC primed seeds showed significantly lower $\mathrm{K}^{+}$loss from the shoot and root than the control under salt stress (Fig. 7c-d), suggesting that PNC nanopriming enabled better $\mathrm{K}^{+}$retention in rapeseed under salt stress. Previous studies showed that higher $\mathrm{K}^{+}$retention is associated with better salt tolerance [17, $19,58]$. In cotton under salt stress, PNC nanopriming resulted in significant lower $\mathrm{K}^{+}$content in root while no difference in cotyledon and hypocotyl [19]. These results suggest that the mechanisms employed in PNC nanopriming improved salt tolerance in rapeseed and cotton are different, indicating the complexity of mechanisms associated with nanopriming improved plant salt tolerance. Moreover, salt stress increased $\mathrm{Na}^{+} / \mathrm{K}^{+}$ratio in the shoot and root of rapeseed seedlings established with or without PNC nanopriming, while PNC priming enable a reduced $\mathrm{Na}^{+} / \mathrm{K}^{+}$ratio in the root and shoot than the control under salt stress (Fig. 7e-f), suggesting that PNC helped to maintain better $\mathrm{Na}^{+} / \mathrm{K}^{+}$ratio than the control under salt stress. $\mathrm{Na}^{+} / \mathrm{K}^{+}$ratio is a hallmark of plant salt tolerance [59]. Together with the $\mathrm{Na}^{+}$and $\mathrm{K}^{+}$ content data, our results suggest that PNC nanopriming could help to maintain $\mathrm{Na}^{+} / \mathrm{K}^{+}$ratio in rapeseed by reduce $\mathrm{Na}^{+}$over-accumulation and $\mathrm{K}^{+}$loss. 


\section{Nanopriming could be a promising way to improve plant salt stress tolerance}

To improve crop production in lands affected by salinity, different strategies have been practiced [60]. Strategies such as water saving irrigation, drainage system, and soil management practices have been applied to promote agricultural production [61, 62]. However, these approaches are expensive which may cost more money on its implementation. Similarly, approaches i.e. screening and breeding of salt tolerant varieties [63], potential use of halophytes [64], and the use of beneficial soil microorganisms [65] could also promote agricultural production in salt affected soils. While these applications require long time. New approaches which are affordable and no time consuming are encouraged to address salinity issue in agricultural production.

Nanotechnology has potential to provide effective solutions to agriculture-related problems [66, 67]. Since the last couple of decades, a significant amount of research has been carried out on the application nanoparticles in agriculture under hostile environmental conditions. For example, to improve salt tolerance in crops, nanoparticles were applied as foliar spray or mixed with soil [68,69]. Application of cerium oxide nanoparticles improved stress tolerance in Moldavian balm [foliar spray application, $50 \mathrm{mg}$ $\mathrm{L}^{-1}$, [70]], soybean [addition to dry soil at the rate of $2000 \mathrm{mg} \mathrm{L}^{-1}$, [71]], and lettuce [addition to the soil at the rate of $100 \mathrm{mg} \mathrm{Kg}^{-1}$ soil, [72]] plants by enhancing antioxidant enzymes activities, osmoreglation, photosynthesis, and water relation. However, foliar or soil application of nanoparticles have some obstacles such as possible high cost and environmental pollution, hindering the adaptation of nanotechnology and its widespread application. Economic viability and biosafety issues are considered as the major obstacles due to the reason that the higher dosage application of nanoparticles could cost more money and also the application process in agricultural land could lead to serious health and environmental risks $[73,74]$. Therefore, nanopriming could be a sustainable strategy which entails a minimum use of nanoparticles by not only reducing the cost due to very small dosage application, but also less risk of nanomaterials on environment. For the current rapeseeds planting mode in China, estimated seed rate for rapeseed in the field is $\sim 5 \mathrm{Kg} /$ hectare. For the nanopriming, we need $25 \mathrm{~mL}(1: 5$ $\mathrm{Kg} / \mathrm{L})$ of priming solution for $5000 \mathrm{~g}$ seeds. Thus, we need about $0.138 \mathrm{~L}$ of PNC $(0.1 \mathrm{mM}$, equal to 11.1 $\mathrm{mg} / \mathrm{L} \mathrm{[16]} \mathrm{for} \mathrm{the} \mathrm{seed} \mathrm{rate/hectare.} \mathrm{Thus,} \mathrm{the} \mathrm{amount} \mathrm{of} \mathrm{PNC} \mathrm{for} \mathrm{rapeseed} \mathrm{nanopriming} \mathrm{(1.5} \mathrm{mg} \mathrm{PNC} \mathrm{for}$ one hectare) is far less than the soil application $\left(1000 \mathrm{mg} \mathrm{Kg}^{-1}\right.$ dry sand and clay mixture, [69] or foliar spray (3400 mg PNC for one hectare, personnel communication to Dr. Lan Zhu at Huazhong Agricultural University) for improving rapeseed salt tolerance. It thus not only reduces the cost, but largely alleviates the concerns about biological effects of nanomaterials in environment.

\section{Conclusion}

In summary, during the priming hours, compared the seeds primed with TES control solution, uptake of PNC by seeds allows more water absorbance, higher antioxidant enzyme (SOD and POD) activities, lower ROS accumulation, higher a-amylase activity (also the upregulation of $A M Y 1$ gene) and total soluble sugar contents. We also found that during the first $1 \mathrm{~h}$ priming, PNC are mainly located at the seed coat. While, at $3 \mathrm{~h}$ and $8 \mathrm{~h}, \mathrm{PNC}$ are gradually absorbed into the cotyledon and the radical (only observed at $8 \mathrm{~h}$ 
priming). After seedling establishment, PNC nanopriming enabled higher antioxidant enzyme (SOD and POD) activities, lower ROS accumulation, and better maintenance of $\mathrm{Na}^{+} / \mathrm{K}^{+}$ratio than the TES control under salt stress. Our results add more knowledge to PNC nanopriming improved salt tolerance in rapeseed. Overall, this could be the first study which investigated the downstream events from nanoparticle distribution, ROS level and antioxidant enzyme activities, and a-amylase activities and its gene expression in seeds during priming hours to the maintenance of ROS homeostasis and $\mathrm{Na}^{+} / \mathrm{K}^{+}$ratio in salt stressed seedlings primed with nanoceria. However, it remains unclear whether the PNC nanopriming improved salt tolerance could last until plant harvest or not. Field or glasshouse experiments are required in further studies. Whether PNC nanopriming could improve the quality of rapeseed such as oil, protein and fatty acid contents or not is also worthy to be studied in future work.

\section{Declarations}

\section{Acknowledgments}

We thank A/Prof. Bo Wang for providing rapeseed seeds, and Mr. Jianbo Cao and Mr. Limin He for their help in TEM imaging at Public Laboratory of Electron Microscopy, Huazhong Agricultural University. This work was supported by the NSFC grant (No. 32071971, 31901464), project 2662020ZKPY001 supported by the Fundamental Research Funds for the Central Universities, and joint project SZYJY2021008 from Huazhong Agricultural University and Agricultural Genomics Institute at Shenzhen, Chinese Academy of Agricultural Sciences to H.W.

\section{Author Contributions}

Conceptualization, H.W., M.N.K, and Z.L.; writing-original draft preparation, H.W., and M.N.K.; conducting experiment, M.N.K, Y.L., Z.K., and L.C.; data analysis; H.W., M.N.K, Y.L., Z.K., L.C., and J.H.; and all authors have read and agreed to the manuscript.

\section{Ethics approval and consent to participate}

Not applicable.

\section{Consent for publication}

Not applicable.

\section{Competing interests}

The authors declare no competing financial interests.

\section{References}


1. Khan MN, Khan Z, Luo T, Liu J, Rizwan M, Zhang J, et al. Seed priming with gibberellic acid and melatonin in rapeseed: Consequences for improving yield and seed quality under drought and nonstress conditions. Ind Crops Prod. 2020;156:112850.

2. Bakhshandeh E, Jamali M. Population-based threshold models: A reliable tool for describing aged seeds response of rapeseed under salinity and water stress. Environ Exp Bot. 2020;176:104077.

3. Qian B, Jing Q, Bélanger G, Shang J, Huffman T, Liu J, et al. Simulated canola yield responses to climate change and adaptation in Canada. Agron J. 2018;110:133-46.

4. Gul B, Ansari R, Flowers TJ, Khan MA. Germination strategies of halophyte seeds under salinity. Environ Exp Bot. 2013;92:4-18.

5. Bakhshandeh E, Gholamhossieni M. Modelling the effects of water stress and temperature on seed germination of radish and cantaloupe. J Plant Growth Regul. 2019;38:1402-11.

6. Rameeh V. Ions uptake, yield and yield attributes of rapeseed exposed to salinity stress. J Soil Sci Plant Nutr. 2012;12:851-61.

7. Bakhshandeh E, Jamali M. Population-based threshold models: A reliable tool for describing aged seeds response of rapeseed under salinity and water stress. Environ Exp Bot. 2020;176:104077.

8. Rajjou L, Duval M, Gallardo K, Catusse J, Bally J, Job C, et al. Seed germination and vigor. Annu Rev Plant Biol. 2012;63:507-33.

9. Raja K, Sowmya R, Sudhagar R, Moorthy PS, Govindaraju K, Subramanian KS. Biogenic ZnO and Cu nanoparticles to improve seed germination quality in blackgram (Vigna mungo). Mater Lett. 2019;235:164-7.

10. Jisha KC, Vijayakumari K, Puthur JT. Seed priming for abiotic stress tolerance: An overview. Acta Physiol Plant. 2013;35:1381-96.

11. Ye Y, Cota-Ruiz K, Hernández-Viezcas JA, Valdés C, Medina-Velo IA, Turley RS, et al. Manganese nanoparticles control salinity-modulated molecular responses in Capsicum annuum L. through priming: A sustainable approach for agriculture. ACS Sustain Chem Eng. 2020;8:1427-36.

12. Almutairi ZM. Influence of silver nano-particles on the salt resistance of tomato (Solanum lycopersicum) during germination. Int J Agric Biol. 2016;18:449-57.

13. Cassee FR, Van Balen EC, Singh C, Green D, Muijser H, Weinstein J, et al. Exposure, health and ecological effects review of engineered nanoscale cerium and cerium oxide associated with its use as a fuel additive. Crit Rev Toxicol. 2011;41:213-29.

14. Wang Q, Ebbs SD, Chen Y, Ma X. Trans-generational impact of cerium oxide nanoparticles on tomato plants. Metallomics. 2013;5:753-9.

15. Rossi L, Zhang W, Ma X. Cerium oxide nanoparticles alter the salt stress tolerance of Brassica napus L. by modifying the formation of root apoplastic barriers. Environ Pollut. 2017;229:132-8.

16. Wu H, Tito N, Giraldo JP. Anionic cerium oxide nanoparticles protect plant photosynthesis from abiotic stress by scavenging reactive oxygen species. ACS Nano. 2017;11:11283-97. 
17. Wu H, Shabala L, Shabala S, Giraldo JP. Hydroxyl radical scavenging by cerium oxide nanoparticles improves Arabidopsis salinity tolerance by enhancing leaf mesophyll potassium retention. Environ Sci Nano. 2018;5:1567-83.

18. Shah T, Latif S, Saeed F, Ali I, Ullah S, Abdullah Alsahli A, et al. Seed priming with titanium dioxide nanoparticles enhances seed vigor, leaf water status, and antioxidant enzyme activities in maize (Zea mays L.) under salinity stress. J King Saud Univ - Sci. 2021;33:101207.

19. An J, Hu P, Li F, Wu H, Shen Y, White JC, et al. Emerging investigator series: molecular mechanisms of plant salinity stress tolerance improvement by seed priming with cerium oxide nanoparticles. Environ Sci Nano. 2020;7:2214-28.

20. Newkirk GM, Wu H, Santana I, Giraldo JP. Catalytic scavenging of plant reactive oxygen species in vivo by anionic cerium oxide nanoparticles. J Vis Exp. 2018;2018:1-11.

21. Mohamed IAA, Shalby N, Bai C, Qin M, Agami RA, Jie K, et al. Stomatal and photosynthetic traits are associated with investigating sodium chloride tolerance of Brassica napus L. cultivars. Plants. 2020;9.

22. Keharom S, Mahachai R, Chanthai $\mathrm{S}$. The optimization study of a-amylase activity based on central composite design-response surface methodology by dinitrosalicylic acid method. Int Food Res J. 2016;23:10-7.

23. Heath RL, Packer L. Photoperoxidation in isolated chloroplasts. Arch Biochem Biophys. 1968;125:189-98.

24. Xu SC, Li YP, Hu J, Guan YJ, Ma WG, Zheng YY, et al. Responses of antioxidant enzymes to chilling stress in tobacco seedlings. Agric Sci China. 2010;9:1594-601.

25. Chakraborty K, Singh AL, Kalariya KA, Goswami N, Zala PV. Physiological responses of peanut (Arachis hypogaea L.) cultivars to water deficit stress: Status of oxidative stress and antioxidant enzyme activities. Acta Bot Croat. 2015;74:123-42.

26. Park MR, Hasenstein KH. Oxygen dependency of germinating Brassica seeds. Life Sci Sp Res. 2016;8:30-7.

27. Ismail ghada, Abou-Zeid $\mathrm{H}$. The role of priming with biosynthesized silver nanoparticles in the response of Triticum aestivum L. to salt stress. Egypt J Bot. 2018;58:73-85.

28. Alves R, de C, Nicolau, Checchio MCM, Sousa Junior MV, G da S, de Oliveira, F de A, Prado RM, et al. Salt stress alleviation by seed priming with silicon in lettuce seedlings: An approach based on enhancing antioxidant responses. Bragantia. 2020;79:19-29.

29. Baz H, Creech M, Chen J, Gong H, Bradford K, Huo H. Water-soluble carbon nanoparticles improve seed germination and post-germination growth of lettuce under salinity stress. Agronomy. 2020;10.

30. Das S, Mukherjee A, Sengupta G, Singh VK. Overview of nanomaterials synthesis methods, characterization techniques and effect on seed germination. Nano-materials as photocatal. degrad. environ. pollut. challenges possibilities. 2020; 371-401.

31. Movafeghi A, Khataee A, Abedi M, Tarrahi R, Dadpour M, Vafaei F. Effects of TiO2 nanoparticles on the aquatic plant Spirodela polyrrhiza: Evaluation of growth parameters, pigment contents and 
antioxidant enzyme activities. J Environ Sci. 2018;64:130-8.

32. Mahakham W, Sarmah AK, Maensiri S, Theerakulpisut P. Nanopriming technology for enhancing germination and starch metabolism of aged rice seeds using phytosynthesized silver nanoparticles. Sci. 2017;7:1-21.

33. Kato-Noguchi H, Macías FA. Effects of 6-methoxy-2-benzoxazolinone on the germination and aamylase activity in lettuce seeds. J Plant Physiol. 2005;162:1304-7.

34. Damaris RN, Lin Z, Yang P, He D. The rice alpha-amylase, conserved regulator of seed maturation and germination. Int J Mol Sci. 2019;20:1-17.

35. Huang P, He L, Abbas A, Hussain S, Hussain S, Du D, et al. Seed priming with sorghum water extract improves the performance of camelina (Camelina sativa L. crantz.) under salt stress. Plants. 2021;10.

36. Sangeetha R. Effect of salinity induced stress and its alleviation on the activity of amylase in the germinating seeds of Zea mays. Int J Basic Life Sci. 2013;1:1-9.

37. Sticher $\mathrm{L}$, Jones RL. A-amylase isoforms are posttranslationally modified in the endomembrane system of the barley aleurone layer. Plant Physiol. 1992;98:1080-6.

38. Zhao M, Zhang H, Yan H, Qiu L, Baskin CC. Mobilization and role of starch, protein, and fat reserves during seed germination of six wild grassland species. Front Plant Sci. 2018;9:1-11.

39. Rosa M, Prado C, Podazza G, Interdonato R, González JA, Hilal M, et al. Soluble sugars-metabolism, sensing and abiotic stress a complex network in the life of plants. Plant Signal Behav. 2009;4:38893.

40. Rawashdeh RY, Harb AM, AlHasan AM. Biological interaction levels of zinc oxide nanoparticles; lettuce seeds as case study. Heliyon. 2020;6:e03983.

41. Guha T, Ravikumar KVG, Mukherjee A, Mukherjee A, Kundu R. Nanopriming with zero valent iron $(\mathrm{nZVI})$ enhances germination and growth in aromatic rice cultivar (Oryza sativa cv. Gobindabhog L.). Plant Physiol. Biochem. 2018; Nanopriming with zero valent iron (nZVI) enhances germination and growth in aromatic rice cultivar (Oryza sativa cv. Gobindabhog L.). Plant Physiol. Biochem. 2018;403-413.

42. Chandrasekaran U, Luo X, Wang Q, Shu K. Are There unidentified factors involved in the germination of nanoprimed seeds? Front Plant Sci. 2020;11:1-6.

43. El-Maarouf-Bouteau H, Bailly C. Oxidative signaling in seed germination and dormancy. Plant Signal Behav. 2008;3:175-82.

44. Pal L, Kar RK. Role of reactive oxygen species in cotyledon senescence during early seedling stage of mung bean [Vigna radiata (L.) Wilczek]. J Plant Growth Regul. 2019;38:315-24.

45. Kurek K, Plitta-Michalak B, Ratajczak E. Reactive oxygen species as potential drivers of the seed aging process. Plants. 2019;8:1-13.

46. Suchanti S, Singh A, Mishra R. Epigenetic modulation by biosynthetic nanomaterials from plants in cancer. Mater Today Proc. 2021;43:3197-3199. 
47. Barba-espín G, Hernández JA, Diaz-vivancos $P$. Role of $\mathrm{H}_{2} \mathrm{O}_{2}$ in pea seed germination. Landes Bioscience. 2012;193-5.

48. Bhardwaj J, Anand A, Nagarajan S. Biochemical and biophysical changes associated with magnetopriming in germinating cucumber seeds. Plant Physiol Biochem. 2012;57:67-73.

49. Anand A, Kumari A, Thakur M, Koul A. Hydrogen peroxide signaling integrates with phytohormones during the germination of magnetoprimed tomato seeds. Sci Rep. 2019;9:1-11.

50. Baldim V, Bedioui F, Mignet N, Margaill I, Berret JF. The enzyme-like catalytic activity of cerium oxide nanoparticles and its dependency on Ce3 + surface area concentration. Nanoscale. 2018;10:697180.

51. Rajkumar MS, Gupta K, Khemka NK, Garg R, Jain M. DNA methylation reprogramming during seed development and its functional relevance in seed size/weight determination in chickpea. Commun Biol. 2020;3:340.

52. Ma X, Geiser-Lee J, Deng Y, Kolmakov A. Interactions between engineered nanoparticles (ENPs) and plants: Phytotoxicity, uptake and accumulation. Sci Total Environ. 2010;408:3053-61.

53. Munns R, Tester M. Mechanisms of salinity tolerance. Annu Rev Plant Biol. 2008;59:651-81.

54. Deinlein U, Stephan AB, Horie T, Luo W, Xu G, Schroeder JI. Plant salt-tolerance mechanisms. Trends Plant Sci. 2014;19:371-9.

55. Wu H, Wang $X, X u M$, Zhang J. The effect of water deficit and waterlogging on the yield components of cotton. Crop Sci. 2018;58:1751-61.

56. Wu H, Zhang X, Giraldo JP, Shabala S. It is not all about sodium: revealing tissue specificity and signalling roles of potassium in plant responses to salt stress. Plant Soil. 2018;431:1-17.

57. Almeida DM, Margarida Oliveira M, Saibo NJM. Regulation of $\mathrm{Na}^{+}$and $\mathrm{K}^{+}$homeostasis in plants: Towards improved salt stress tolerance in crop plants. Genet Mol Biol. 2017;40:326-45.

58. Zhang L, Ma H, Chen T, Pen J, Yu S, Zhaoe X. Morphological and physiological responses of cotton (Gossypium hirsutum L.) plants to salinity. PLoS One. 2014;9(11):e112807.

59. Chen YC, Chang HS, Lai HM, Jeng ST. Characterization of the wound-inducible protein ipomoelin from sweet potato. Plant Cell Environ. 2005;28:251-9.

60. Abberton M, Batley J, Bentley A, Bryant J, Cai H, Cockram J, et al. Global agricultural intensification during climate change: A role for genomics. Plant Biotechnol J. 2016;14:1095-8.

61. Shtull-Trauring E, Cohen A, Ben-Hur M, Tanny J, Bernstein N. Reducing salinity of treated waste water with large scale desalination. Water Res. 2020;186:116322.

62. Leogrande R, Vitti C. Use of organic amendments to reclaim saline and sodic soils: a review. Arid $L$ Res Manag. 2019;33:1-21.

63. Hanin M, Ebel C, Ngom M, Laplaze L, Masmoudi K. New insights on plant salt tolerance mechanisms and their potential use for breeding. Front Plant Sci. 2016;7:1-17.

64. Hasanuzzaman M, Nahar K, Alam MM, Bhowmik PC, Hossain MA, Rahman MM, et al. Potential use of halophytes to remediate saline soils. Biomed Res Int. 2014;2014. 
65. Shrivastava P, Kumar R. Soil salinity: A serious environmental issue and plant growth promoting bacteria as one of the tools for its alleviation. Saudi J Biol Sci King Saud University. 2015;22:12331.

66. Lv M, Liu Y, Geng J, Kou X, Xin Z, Yang D. Engineering nanomaterials-based biosensors for food safety detection. Biosens Bioelectron. 2018;106:122-8.

67. Chen YW, Lee HV, Juan JC, Phang SM. Production of new cellulose nanomaterial from red algae marine biomass Gelidium elegans. Carbohydr Polym. 2016;151:1210-9.

68. Shang Y, Hasan K, Ahammed GJ, Li M, Yin H. Shang. Applications of nanotechnology in plant growth and crop protection: a review. Molecules. 2019;24:2558.

69. Rossi L, Zhang W, Lombardini L, Ma X. The impact of cerium oxide nanoparticles on the salt stress responses of Brassica napus L. Environ Pollut. 2016;219:28-36.

70. Mohammadi MHZ, Panahirad S, Navai A, Bahrami MK, Kulak M, Gohari G. Cerium oxide nanoparticles (CeO2-NPs) improve growth parameters and antioxidant defense system in Moldavian Balm (Dracocephalum moldavica L.) under salinity stress. Plant Stress. 2021;1:100006.

71. Cao Z, Rossi L, Stowers C, Zhang W, Lombardini L, Ma X. The impact of cerium oxide nanoparticles on the physiology of soybean (G/ycine $\max (\mathrm{L}$.) Merr.) under different soil moisture conditions. Environ Sci Pollut Res. 2018;25:930-9.

72. Gui X, Zhang Z, Liu S, Ma Y, Zhang P, He X, et al. Fate and phytotoxicity of CeO2 nanoparticles on lettuce cultured in the potting soil environment. PLoS One. 2015;10:1-10.

73. Iavicoli I, Leso V, Beezhold DH, Shvedova AA. Nanotechnology in agriculture: Opportunities, toxicological implications, and occupational risks. Toxicol Appl Pharmacol. 2017;329:96-111.

74. Mukhopadhyay SS. Nanotechnology in agriculture: Prospects and constraints. Nanotechnol Sci Appl. 2014;7:63-71.

\section{Figures}


Figure 1
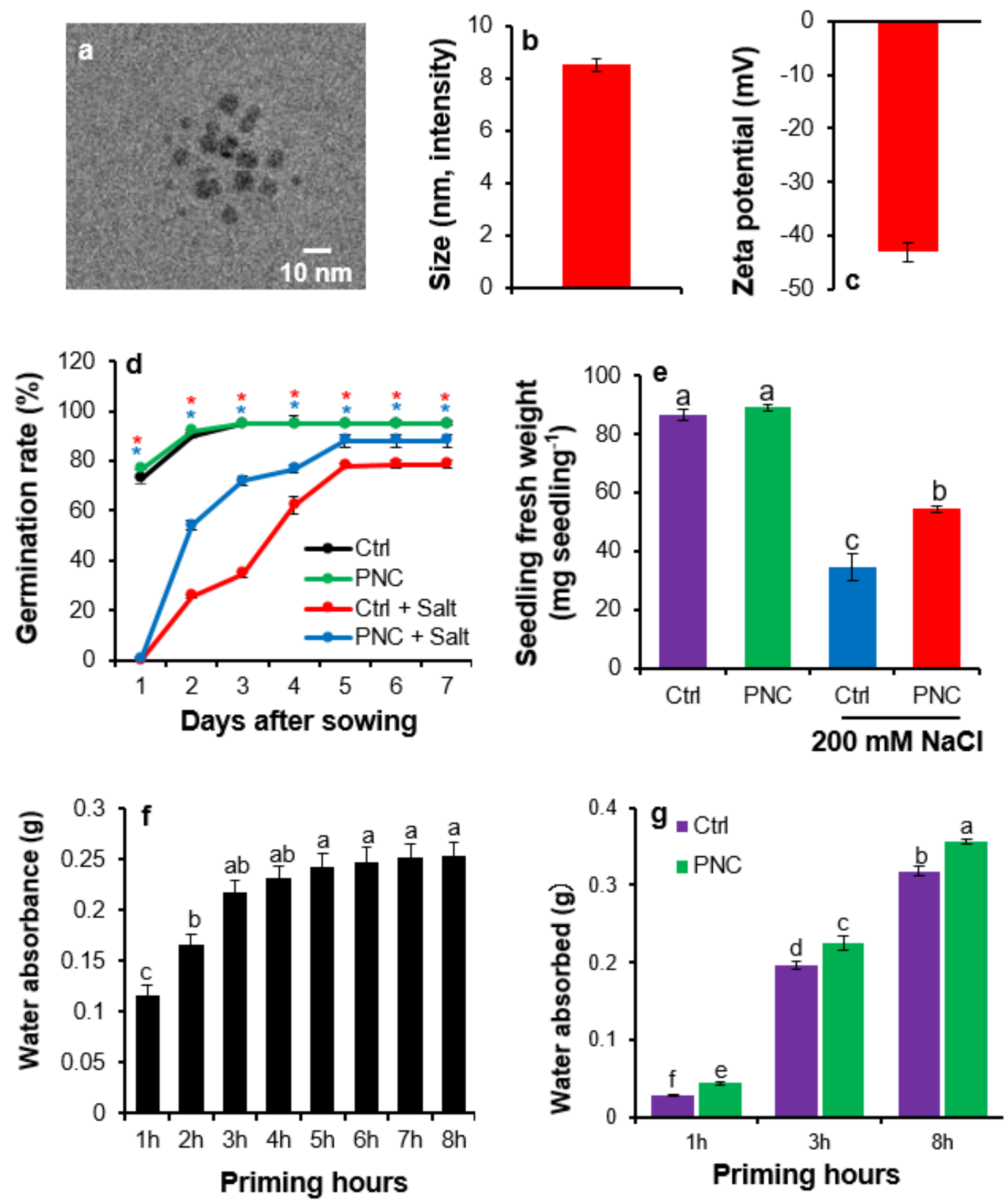

Figure 1

Characterization of cerium oxide nanoparticles (PNC) and the effect of PNC nanopriming on seed germination and fresh weight of rapeseed under salt stress. a, TEM image of PNC, b, PNC size by intensity, c, zeta potential of PNC, $d$ and e, the effect of PNC priming on rapeseed germination rate and fresh weight of rapeseed seedlings under salt stress or non-saline condition, $\mathrm{f}$, water uptake by rapeseed seed from 1 to 8 priming hours with an interval of 1 hour, g, comparison of absorbed water content 
between PNC priming and control during $1 \mathrm{~h}, 3 \mathrm{~h}$, and $8 \mathrm{~h}$. Different lowercase alphabets on the vertical bars or * indicates significant difference at $\mathrm{P}<0.05$. Error bars are the representative of standard deviation of three biological replicates (one batch as one biological replicates) $(n=3)$.

Figure 2
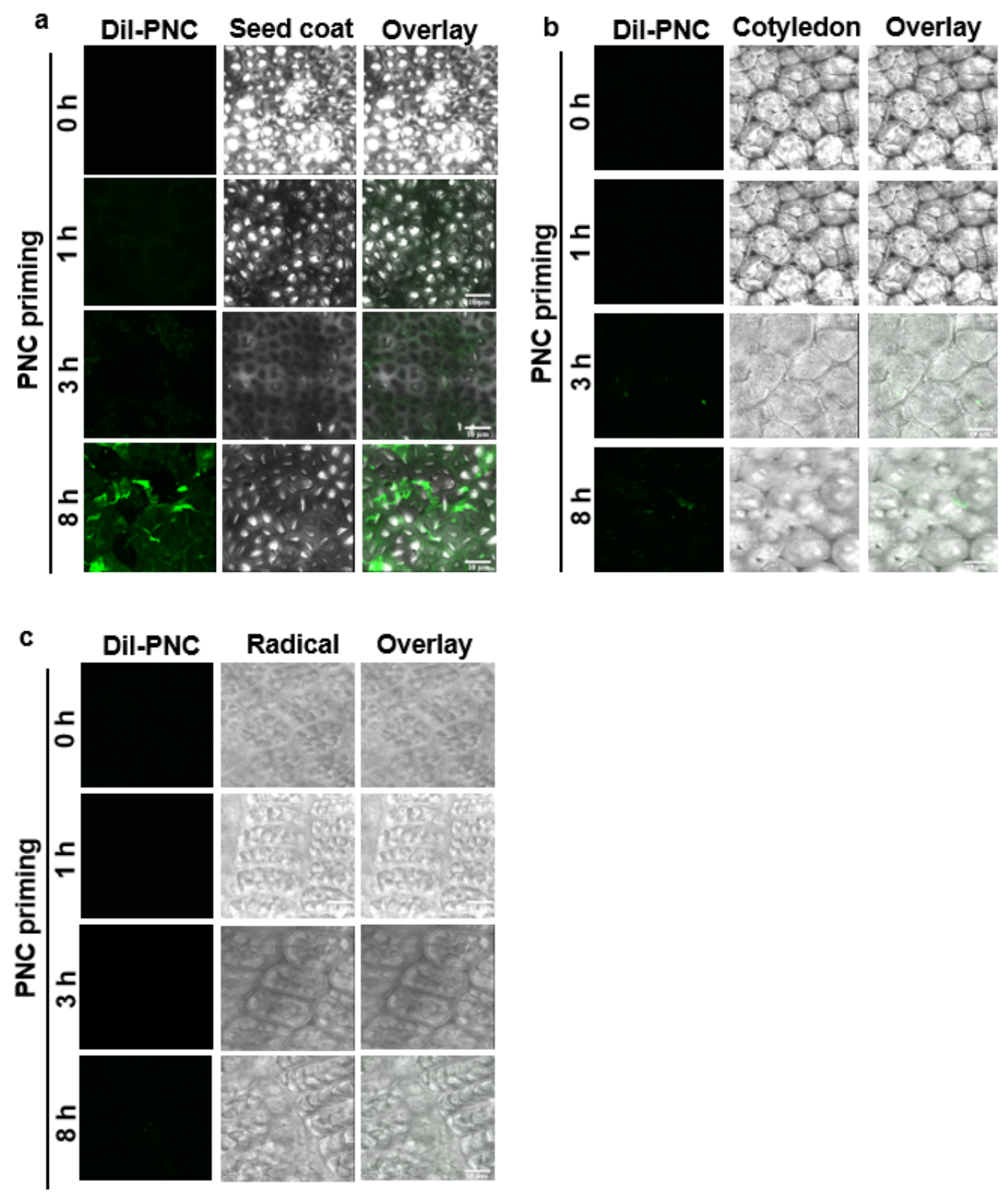

Figure 2

Confocal imaging of Dil-PNC distribution in seed coat of the PNC primed seeds. Dil-PNC signal in seed coat (a), cotyledon (b), and radical (c) of rapeseed with PNC priming at $1 \mathrm{~h}, 3 \mathrm{~h}$, and $8 \mathrm{~h}$ of priming. Scale 
Figure 3
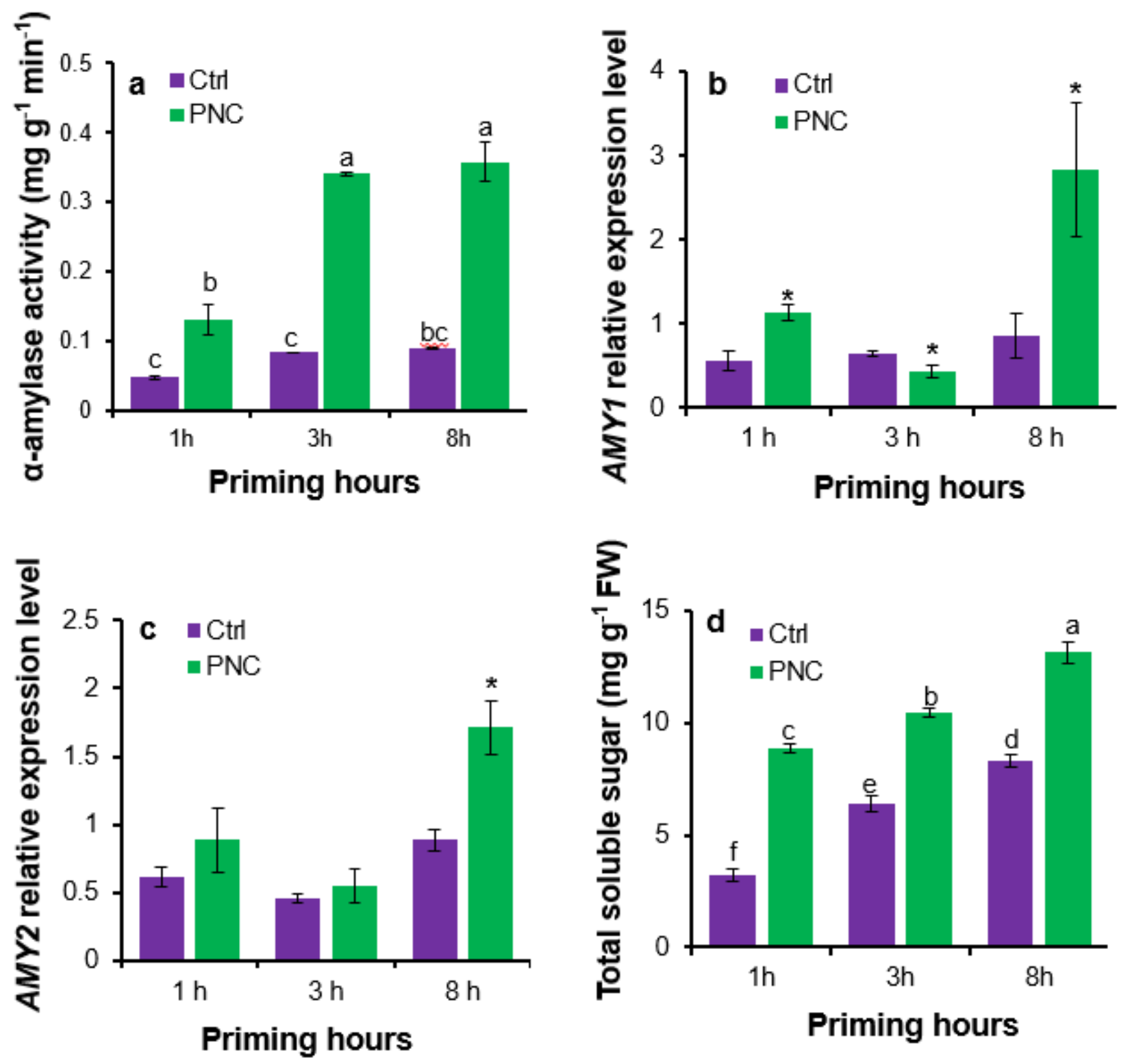

Figure 3

PNC nanopriming modulates the activities of a-amylase in seeds. a, a-amylase activity in seeds primed with or without PNC at 1, 3, and 8 priming hours, $b$ and $c$, relative expression level of AMY1 and AMY2 genes in seeds primed with or without PNC at 1, 3, and 8 priming hours, and d, total soluble sugar content in seeds primed with or without PNC at 1, 3, and 8 priming hours. Different lowercase alphabets on the vertical bars or * indicates significant difference at $P<0.05$. Error bars are the representative of standard error of three biological replicates (one batch as one biological replicates) $(n=3)$. 
Figure 4
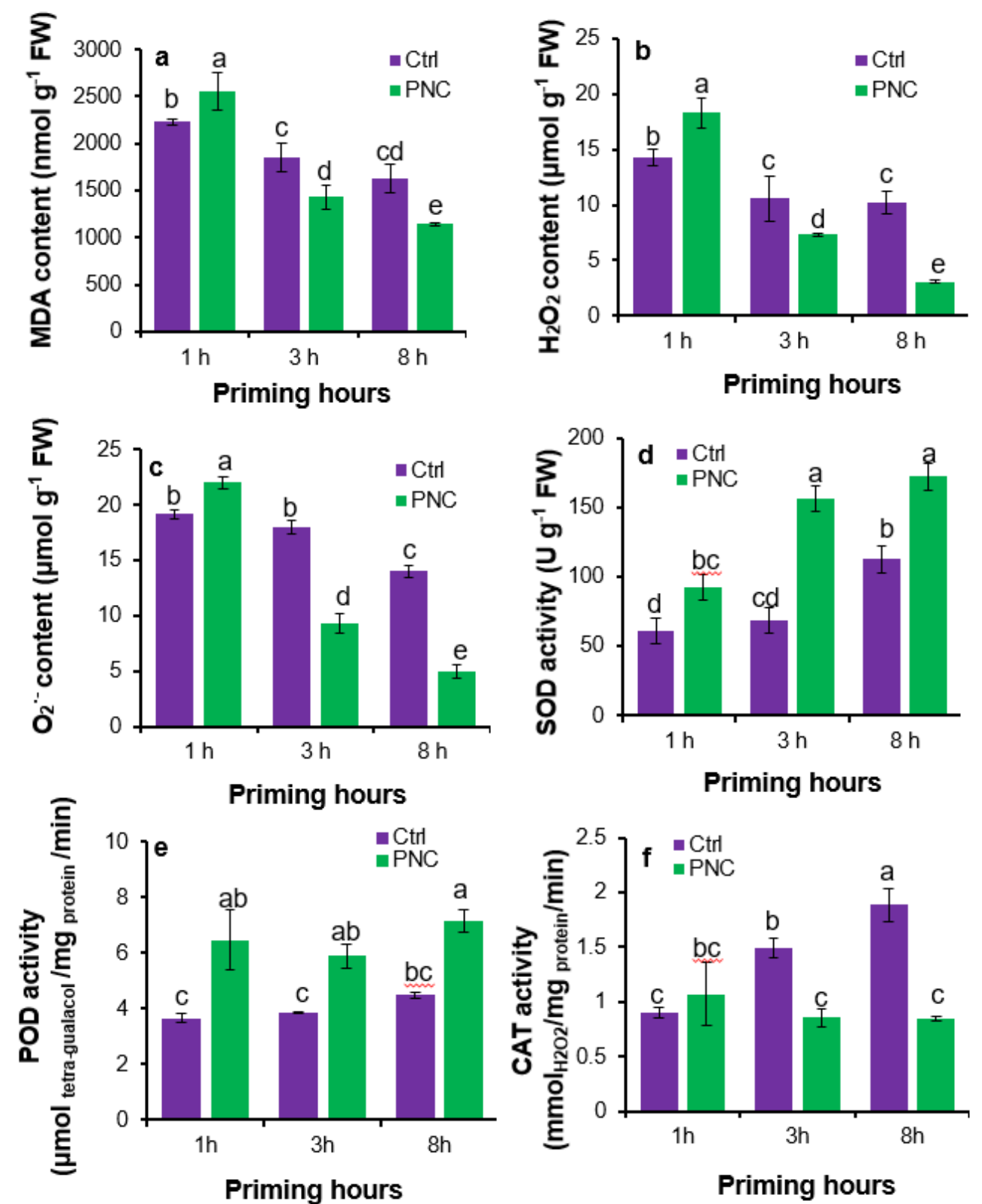

Priming hours

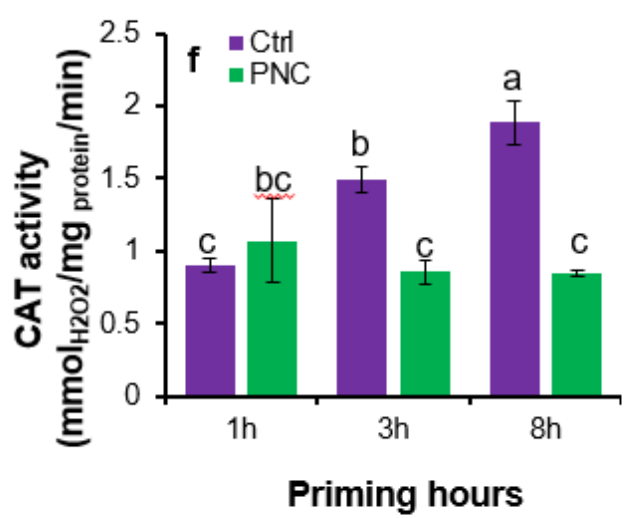

\section{Figure 4}

PNC nanopriming modulates ROS homeostasis and antioxidant enzymes activities in seeds. MDA content (a), H2O2 content (b), $\cdot 02-$ content (c), SOD activity (d), POD activity (e), and CAT activity (f) in seeds primed with or without PNC at 1, 3, and 8 priming hours. Different lowercase alphabets on the vertical bars indicates significant difference at $P<0.05$. Error bars are the representative of standard error of three biological replicates (one batch as one biological replicates) $(n=3)$. 
Figure 5
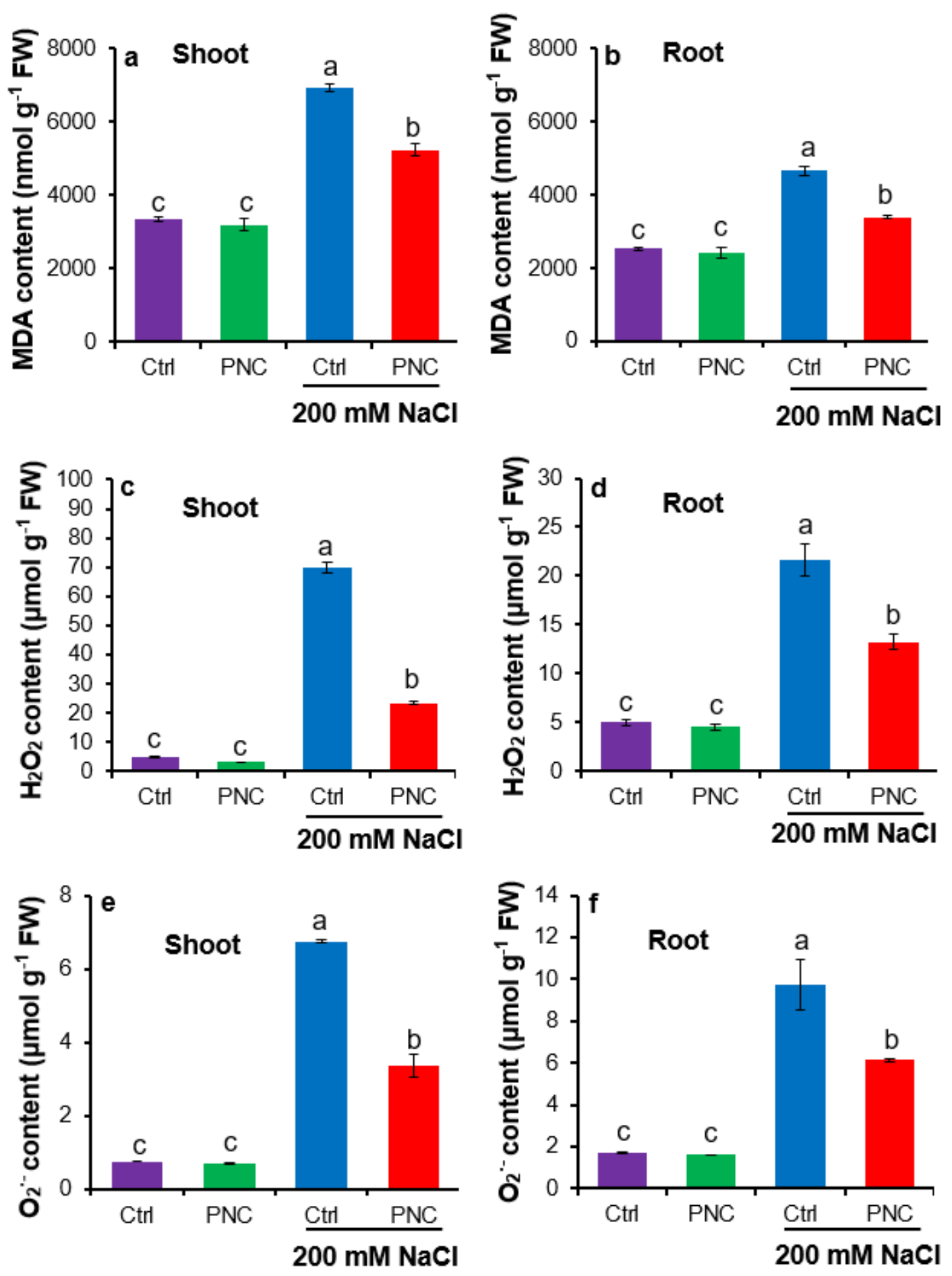

Figure 5

PNC nanopriming modulates ROS level in salt stressed seedlings established from the primed seeds. MDA content ( $a$ for shoot, b for root), $\mathrm{H} 2 \mathrm{O} 2$ content (c for shoot, $d$ for root), and $\cdot 02$ - content (e for shoot, $f$ for root) in seedlings established from seeds primed with or without PNC under $200 \mathrm{mM} \mathrm{NaCl}$ stress (7 days) or non-saline condition. Different lowercase alphabets on the vertical bars indicates 
significant difference at $\mathrm{P}<0.05$. Error bars are the representative of standard error of three biological replicates (one batch as one biological replicates) $(n=3)$.

Figure 6
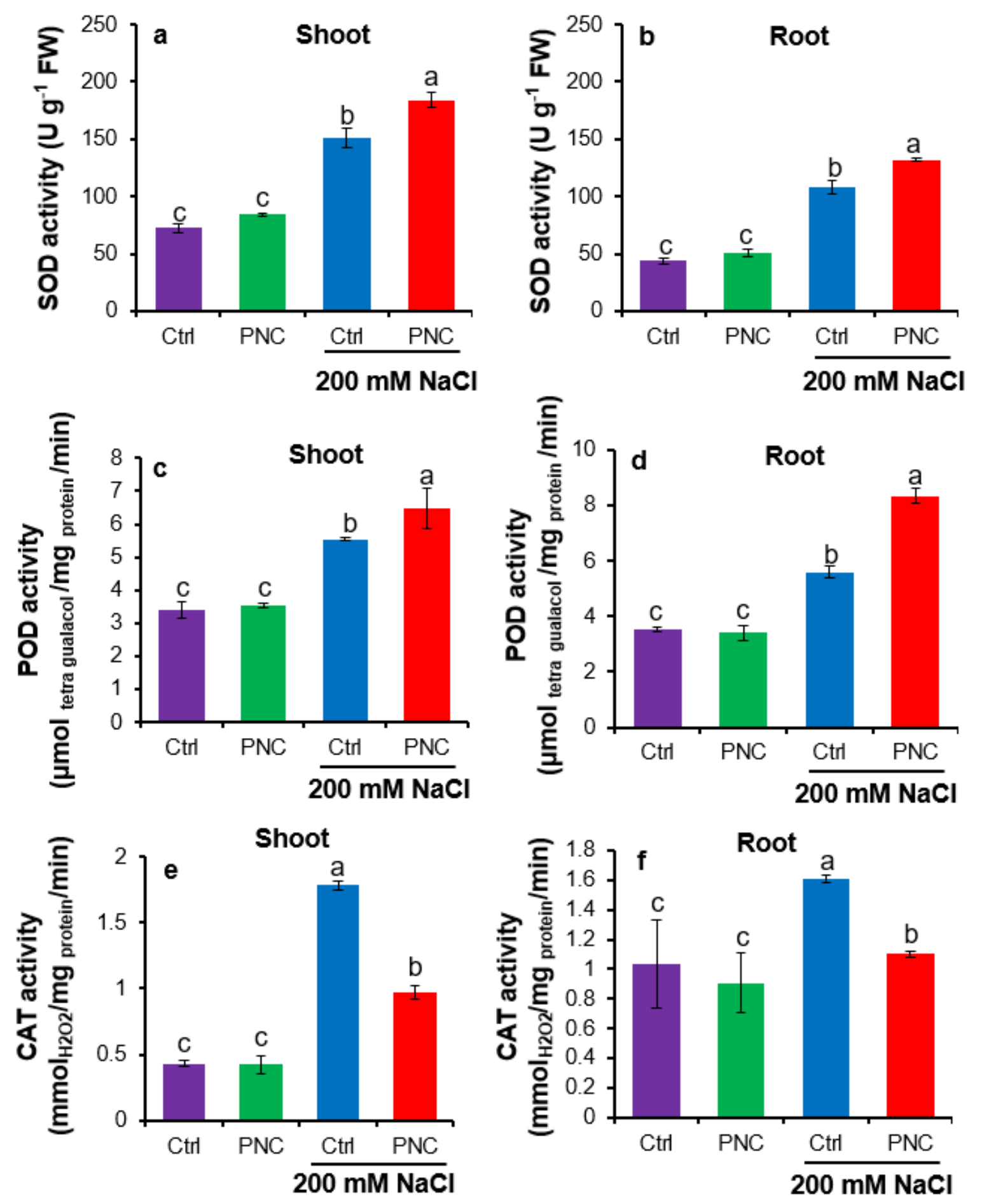

Figure 6

PNC nanopriming modulates antioxidant enzyme activities in salt stressed seedlings established from the primed seeds. Activities of SOD enzyme ( $a$ for shoot, $b$ for root), POD enzyme ( $c$ for shoot, $d$ for root), and CAT enzyme (e for shoot, $f$ for root) in seedlings established from seeds primed with or without PNC 
under $200 \mathrm{mM} \mathrm{NaCl}$ stress (7 days) or non-saline condition. Different lowercase alphabets on the vertical bars indicates significant difference. Error bars are the representative of standard error of three biological replicates (one batch as one biological replicates) $(n=3)$.
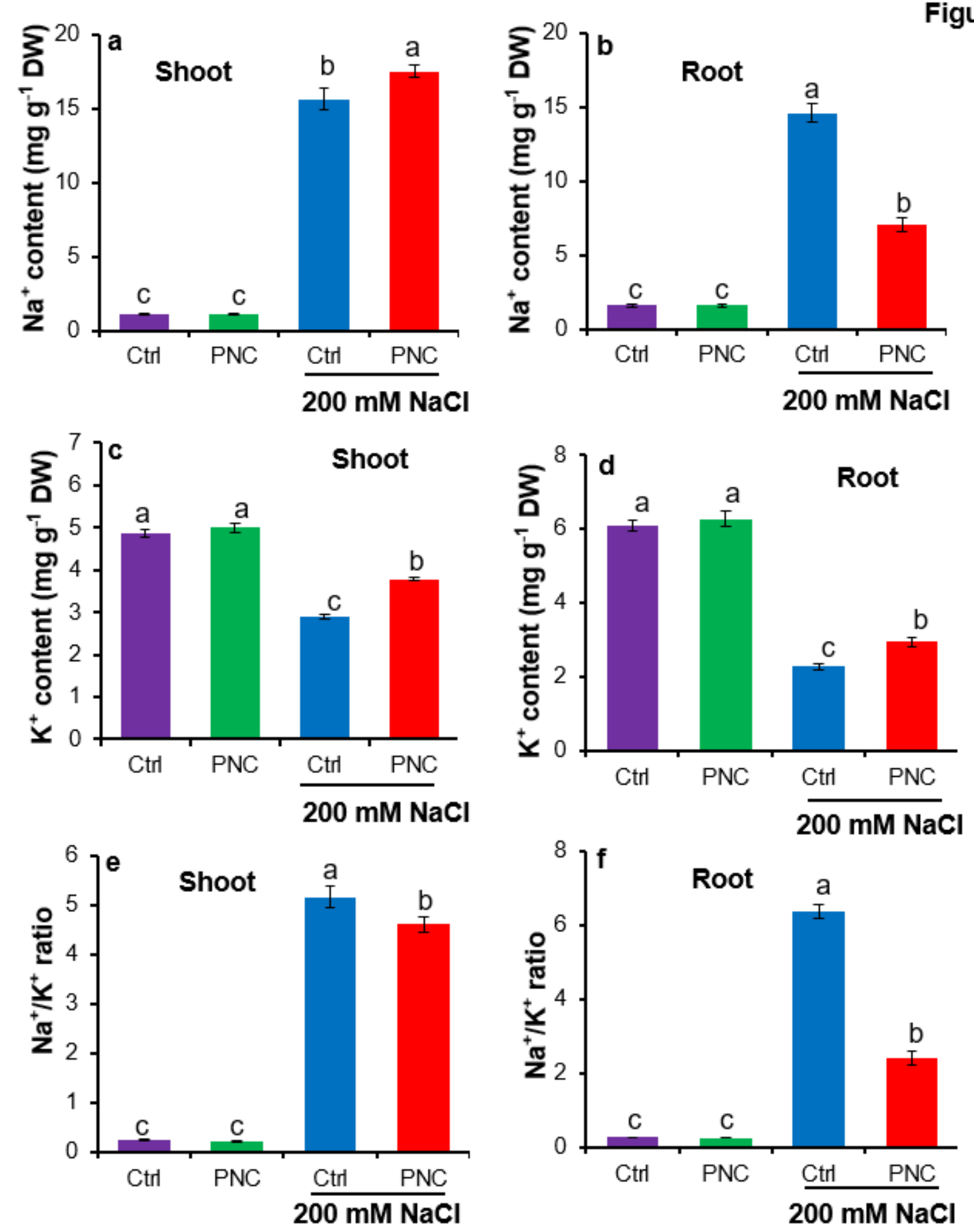

Figure 7

PNC nanopriming modulates $\mathrm{Na}+$ and $\mathrm{K}+$ content and $\mathrm{Na}+/ \mathrm{K}+$ ratio in rapeseed shoot and root under salt stress. $\mathrm{Na}+$ content (a for shoot, b for root), $\mathrm{K}+$ content (c for shoot, $d$ for root), and $\mathrm{Na}+\mathrm{K}+$ ratio (e for 
shoot, $f$ for root) in seedlings established from seeds primed with or without PNC under $200 \mathrm{mM} \mathrm{NaCl}$ stress (7 days) or non-saline condition. Different lowercase alphabets on the vertical bars indicates significant difference at $P<0.05$. Error bars are the representative of standard error of three biological replicates (one batch as one biological replicates) $(n=3)$.

\section{Supplementary Files}

This is a list of supplementary files associated with this preprint. Click to download.

- Supportinginformation.pptx

- GraphicalAbstract.pptx 